\title{
Microbially Induced Sedimentary Structures Recording an Ancient Ecosystem in the ca. 3.48 Billion-Year-Old Dresser Formation, Pilbara, Western Australia
}

\author{
Nora Noffke, Daniel Christian, David Wacey, ${ }^{2,3}$ and Robert M. Hazen ${ }^{4}$
}

\begin{abstract}
Microbially induced sedimentary structures (MISS) result from the response of microbial mats to physical sediment dynamics. MISS are cosmopolitan and found in many modern environments, including shelves, tidal flats, lagoons, riverine shores, lakes, interdune areas, and sabkhas. The structures record highly diverse communities of microbial mats and have been reported from numerous intervals in the geological record up to 3.2 billion years $(\mathrm{Ga})$ old. This contribution describes a suite of MISS from some of the oldest well-preserved sedimentary rocks in the geological record, the early Archean (ca.3.48 Ga) Dresser Formation, Western Australia. Outcrop mapping at the meter to millimeter scale defined five sub-environments characteristic of an ancient coastal sabkha. These sub-environments contain associations of distinct macroscopic and microscopic MISS. Macroscopic MISS include polygonal oscillation cracks and gas domes, erosional remnants and pockets, and mat chips. Microscopic MISS comprise tufts, sinoidal structures, and laminae fabrics; the microscopic laminae are composed of primary carbonaceous matter, pyrite, and hematite, plus trapped and bound grains. Identical suites of MISS occur in equivalent environmental settings through the entire subsequent history of Earth including the present time. This work extends the geological record of MISS by almost 300 million years. Complex matforming microbial communities likely existed almost 3.5 billion years ago. Key Words: Archean—BiofilmsMicrobial mats-Early Earth—Evolution. Astrobiology 13, 1103-1124.
\end{abstract}

\section{Microbially Induced Sedimentary Structures and the Early Record of Life on Earth}

$\mathbf{T}$ HE FOSSIL RECORD of the earliest life on Earth is sparse, and reconstructing the most ancient biota is challenging. Current interpretations of the diversity of Earth's earliest life come predominantly from stromatolites (e.g., Lowe, 1980; Walter et al., 1980; Byerly et al., 1986; Hofmann et al., 1999; Allwood et al., 2006, 2007, 2009, 2010; Hickman, 2012), organic microfossils of prokaryotes and biofilms (e.g., Awramik et al., 1983; Walsh and Lowe, 1985, 1999; Walsh, 1992; Hofmann, 2004; Schopf et al., 2007; Schopf and Bottjer, 2009; Sugitani et al., 2010; Wacey et al., 2011, 2012; Hickman 2012), and isotopic signatures of carbon and sulfur (e.g., Shen et al., 2001, 2009; Ueno et al., 2006, 2008; Wacey et al., 2010). Microbially induced sedimentary structures (MISS) provide an additional way to decode life in ancient sediments (review in Noffke, 2010).
Microbially induced sedimentary structures are created by microbial mats colonizing most aquatic environments, including shelves, tidal flats, lagoons, riverine shores, lakes, dune fields, and sabkhas (e.g., Gerdes and Krumbein, 1987; volume by Hagadorn et al., 1999; Eriksson et al., 2000; Prave, 2002; volume by Schieber et al., 2007; Beraldi-Campesi et al., 2009; volume by Noffke, 2009; Noffke, 2010; volume by Noffke and Chafetz, 2012). In contrast to stromatolites, MISS arise exclusively from the response of microbiota to physical sediment dynamics. Syngenetic mineral production within the organic matrix of the microbial mat provided by the extracellular polymeric substances (EPS) as seen in stromatolites (e.g., Reid et al., 2000; Dupraz et al., 2009; Decho et al., 2011) does not commonly take place (Noffke and Awramik, 2013). Occasionally, mineral precipitates do occur but are only of a temporary nature (e.g., Kremer et al., 2008). The formation of MISS is divided into two steps, first the primary shaping by physical sediment dynamics and second the

\footnotetext{
${ }^{1}$ Old Dominion University, Department of Ocean, Earth and Atmospheric Sciences, Norfolk, Virginia, USA.

${ }^{2}$ Department of Earth Sciences and Centre for Geobiology, University of Bergen, Norway.

${ }^{3}$ Australian Research Council Centre of Excellence for Core to Crust Fluid Systems, Centre for Microscopy Characterisation and Analysis, and Centre for Exploration Targeting, The University of Western Australia, Perth, Australia.

${ }^{4}$ Carnegie Institution of Washington, Geophysical Laboratory, Washington, DC, USA.
} 
diagenetic mineralization of organic material. This will be explained in the following (see Noffke, 2010, for details).

The MISS-forming microbial mats react to sediment dynamics (erosion, deposition, and latency) in four various ways (quantification of primary processes in Noffke and Krumbein, 1999; Noffke, 1999). (i) Erosive stress by water currents passing over the mat-overgrown sedimentary surface triggers biostabilization (Paterson et al., 1994). If affected by erosive stress, the microbial filaments arrange parallel to the depositional surface; the network of filaments interweaves the sediment grains, and the EPS switch, in a fraction of a second, their biomolecular structure to be flexible and ductile (e.g., Stoodley et al., 2002). These microbial effects prohibit the removal of sediment grains by currents. This biostabilization increases the resistance of a sedimentary surface by up to 12 magnitudes (epibenthic microbial mats), 3-5 magnitudes (endobenthic microbial mats), and around 0.02 magnitudes (biofilm-type overgrowth) (Noffke and Krumbein, 1999). (ii) If a microbial mat is exposed to deposition of sediment, the filaments rearrange and orient themselves perpendicular to the sedimentmat surface. They reach into the supernatant water, causing microzones of turbulent disturbance of the water current. This effect is called "baffling" and induces the fall-out of sediment grains suspended in the water. The microbial mat then builds the grains into the mat matrix, either by filaments migrating around them or by sticky EPS gluing the grains together and fixing them in their positions. Baffling and trapping are active sediment accumulation processes. Dependent on the mat
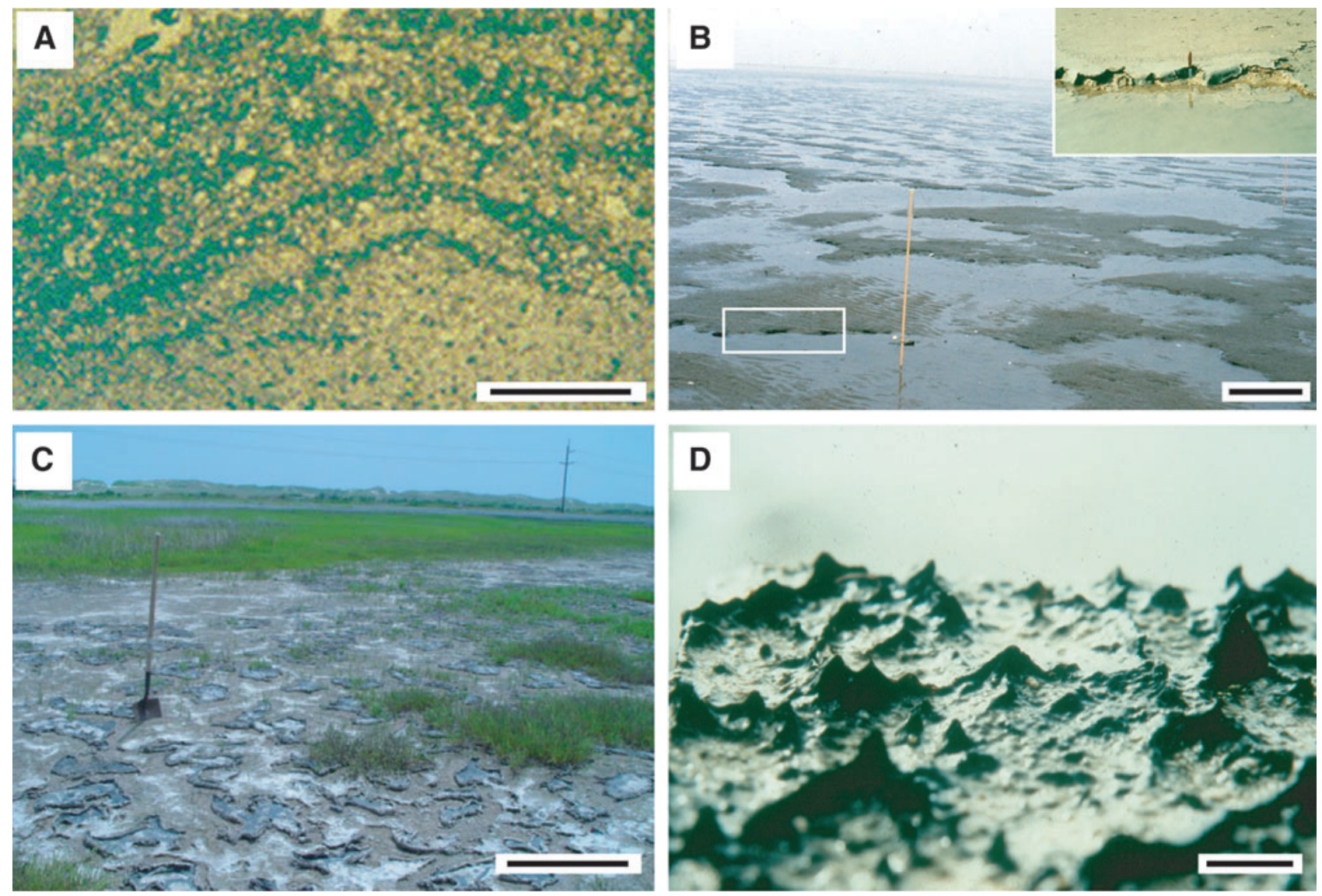

FIG. 1. Examples of modern microbially induced sedimentary structures (MISS). (A) Sinoidal structure visible in vertical section of a modern sediment (sabkha Bahar Alouane, Tunisia, 1996). The dark laminae are biofilms that originally covered the crests and valleys of ripple marks that once were located on top of the sedimentary surface. The ripple marks are now buried, but the organic matter of their biofilm coating is still visible. Scale: $1 \mathrm{~cm}$. (B) Erosional remnants and pockets. The surface of the tidal flats of Mellum Island, Germany (September 1994), is arranged into elevated surface portions overgrown by microbial mats. In the deeper surface portions the sediment is exposed and rippled by the flood currents. Scale: $1 \mathrm{~m}$. The insert shows the edge of an erosional remnant along which the microbial mat is hanging down like a tissue. The sediment originally beneath the fringed edge of the microbial mat was eroded away by currents. This erosion along the erosional remnants broadens the erosional pockets. The erosive current also may rip off individual, centimeter-scale fragments from the fringed microbial mat margin. Scale: knife, $10 \mathrm{~cm}$. (C) Polygonal oscillation cracks. During seasons of sustained aridity, microbial mats dry and shrink. Polygons of microbial mat form, each separated by a crack exposing the sediment beneath the microbial mat. The image shows the first generation of polygons of microbial mat still early in the year; the mat is not yet dense enough to trap gas beneath and to cause gas domes. Portsmouth Island, North Carolina, USA (September 2005). Scale: $1 \mathrm{~m}$. (D) Honeycomb pattern of tufts and ridges, lateral view. This close-up shows the triangular tufts oriented perpendicular to the microbial mat surface. These tufts are composed of filamentous cyanobacteria that move along each other in an upward direction, a migration probably coordinated by cell-cell communication and quorum sensing. Sabkha Bahar Alouane, Tunisia (1996). Scale: $0.5 \mathrm{~cm}$. 
types, grain size selection or heavy mineral enrichment either takes place or not. (iii) Binding is the initial organization of randomly distributed microbial cells and trichomes into a highly structured biofilm community. The microbes communicate with each other and move into a position within the sediment that allows both optimal access to light and/or nutrients and cooperative interaction with the metabolism of neighboring microorganisms. This active arranging takes place during times of quiet sediment dynamic conditions. (iv) Growth, which does not play a role in binding, is a process dependent on availability of nutrients and/or light and not on sediment dynamic conditions; it is biomass enrichment by cell replication and the production of EPS. As a result of their differing modes of genesis, MISS show different morphologies from those of stromatolites (Noffke and Awramik, 2013). Seventeen main types of MISS ranging from centimeter squared to kilometer squared scales have so far been distinguished and both their genesis and resulting morphologies quantified (Noffke, 2010; see also volumes edited by Hagadorn et al., 1999; Schieber et al., 2007; Noffke and Paterson, 2008; Noffke and Chafetz, 2012). Common examples are given in Fig. 1.

While MISS are formed by these primary processes, they are preserved by secondary, diagenetic processes. MISS are lithified by rapid in situ mineralization of the organic matter of the mats, including the microbial cells, trichomes, and filaments, as well as the EPS. In thin sections perpendicular to ancient mat layers, the network of fossil microbes is commonly visible as intertwined and bent laminae. The network includes fossil EPS and (formerly) allochthonous sedimentary grains that once were bound by the mat during its lifetime. However, the appearance of fossil mat texture in MISS differs fundamentally from that of organic microfossils in chert. This difference arises from the preservation of the MISS. Microbial mats in siliciclastic sedimentary rocks are preserved by replacement minerals, not by impregnation as is the case for organic microfossils or organic biofilms in primary chert (e.g., Walsh, 1992; Walsh and Lowe, 1999; Tice and Lowe, 2006; Schopf and Bottjer, 2009; Wacey, 2009). In contrast to such organic material so precisely preserved in chert, the mat texture-forming laminae in MISS have no discrete outline (Noffke 2000; Noffke et al., 2002, 2003, 2006a, 2006b, 2008). In MISS, the laminae appear "cloudy" with diffuse borders. The reason for this appearance is that during the diagenetic alteration of the mat, the chemical compounds of the organic matter released by microbial decomposition diffuse away from their original microsite (e.g., Krumbein et al., 1979; Knoll et al., 1988; Beveridge, 1989; Urrutia and Beveridge, 1994; Konhauser et al., 1994; Schulze-Lam et al., 1996; review on these studies in Noffke, 2010). They react with chemical compounds prevailing in the surrounding water, resulting in initial hydrated "amorphous" mineral precipitates. These initial hydrated mineral precipitates

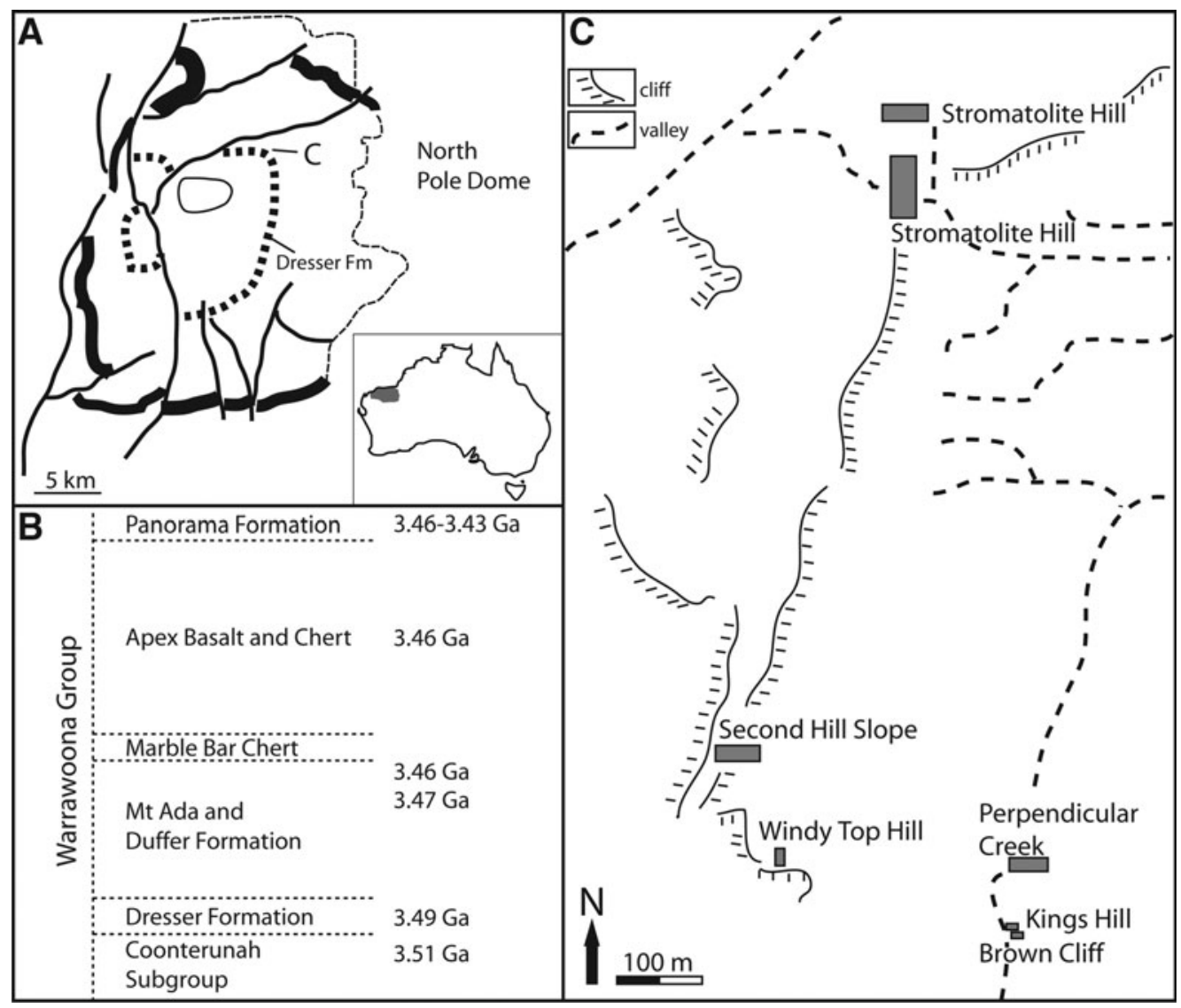

FIG. 2. Location and stratigraphic setting of the Dresser Formation. (A) The Dresser Formation outcrops in a roughly circular pattern in the North Pole Dome area, Pilbara Craton, Western Australia (after Van Kranendonk, 2006; Van Kranendonk et al., 2008). (B) The Dresser Formation has an age of approximately 3.48 Ga. (C) Geographical locations of the stratigraphic sections studied (details in Fig. 3). 
accumulate at nucleation sites and gradually dehydrate and shrink in the course of diagenesis. The dehydration and recrystallization lead to mineral phases of higher crystallinity. At the microscopic scale, the minerals that replace microbial mats therefore are arranged as irregular clots lining the original shape of the laminae. This is in stark contrast to microfossils preserved in chert, where the organic matter was entombed rapidly by synsedimentary silicification and impregnation, and detailed preservation of cells was possible (e.g., Cady and Farmer, 1996). For this reason, very high spatial resolution analytical techniques such as transmission electron microscopy (TEM) or secondary ion mass

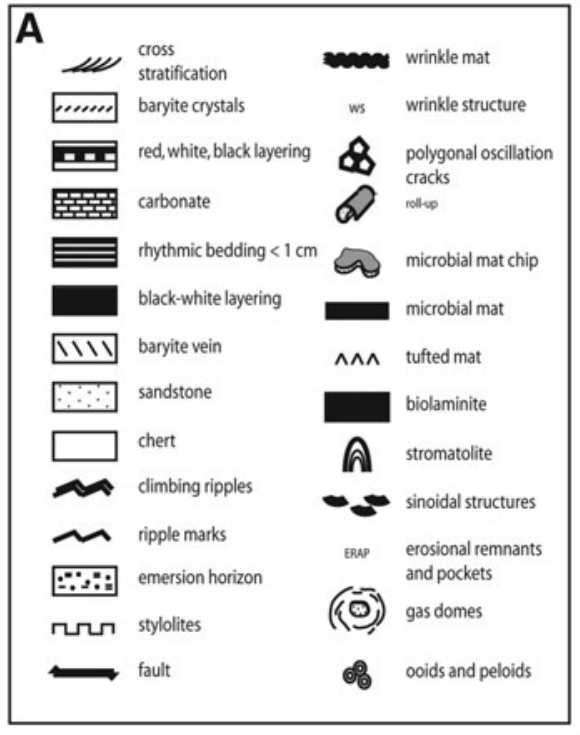

C

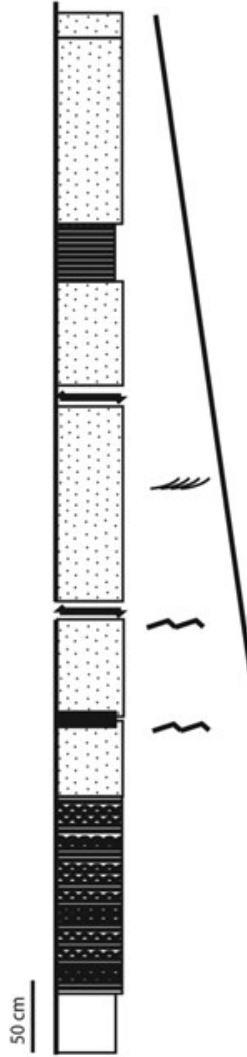

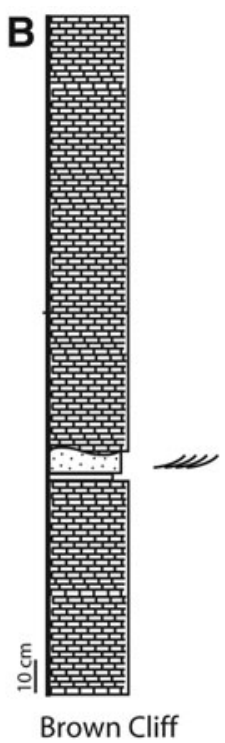

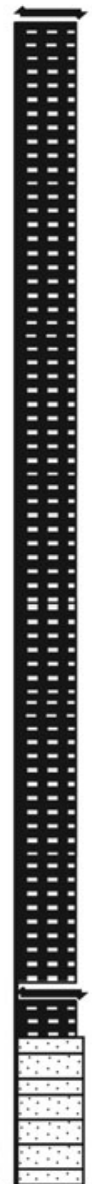

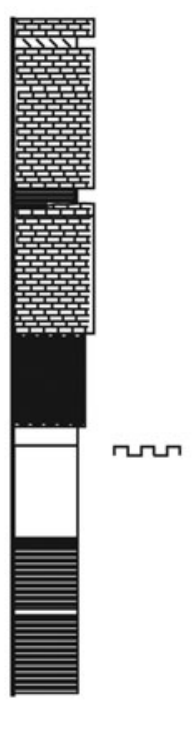
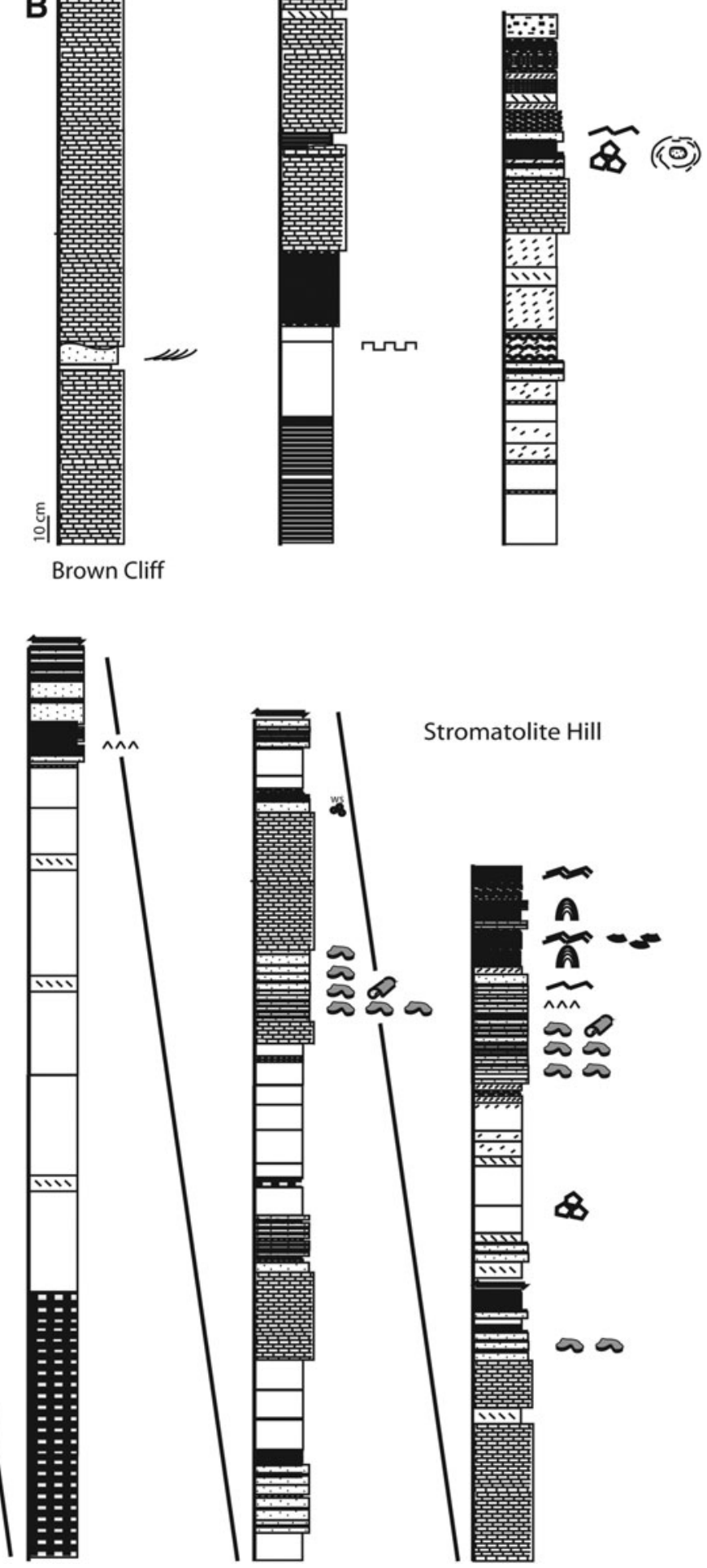

FIG. 3. Stratigraphic sections studied, 3.48 Ga Dresser Formation, Pilbara, Western Australia. (A) to (H) Detailed stratigraphic profiles documenting lithology and sedimentary structures. Where the lithology could not be determined anymore the signature was left blank. 


\section{D}
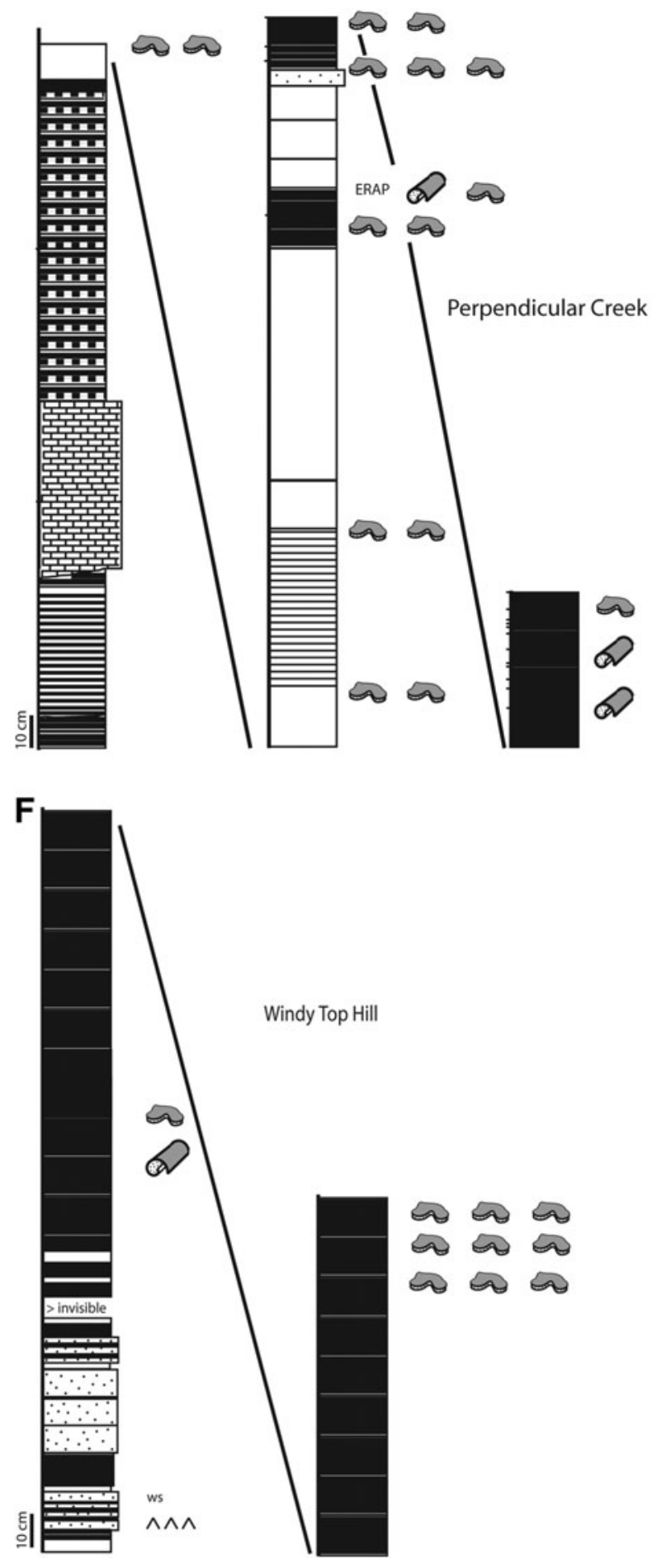
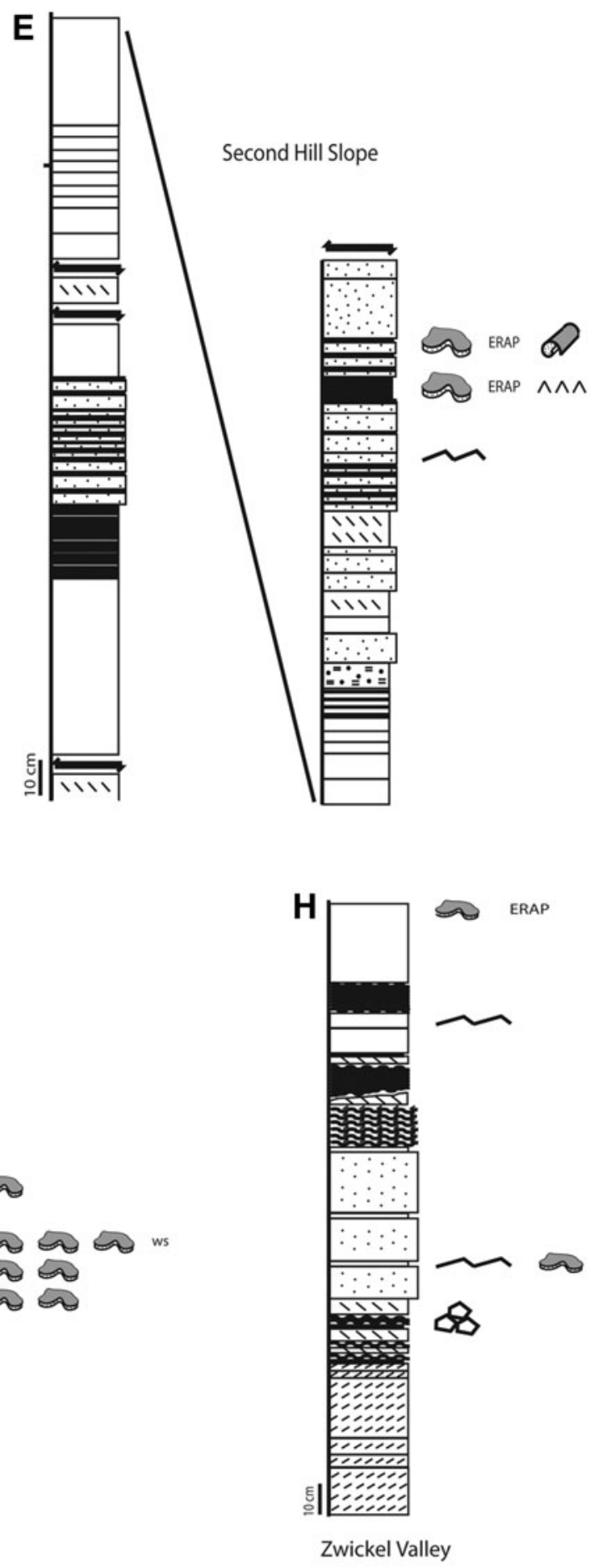

FIG. 3. (continued).

spectrometry (SIMS and Nano-SIMS) are not particularly useful for resolving morphological characteristics of MISSforming microbial cells. To acknowledge these differences in preservation, the MISS literature uses the terms "laminae" and "filament-like texture" instead of "filament" or "trichome." In the fossilized examples from younger Archean, Proterozoic, and Phanerozoic time periods, the ancient mat fabrics may still include some original carbon, but the orig- inal organic matter is largely replaced by pyrite, hematite, and goethite (review in Noffke, 2010).

A set of seven biogenicity criteria for MISS has been developed and tested in numerous comparative studies (overview in Noffke, 2010). The first four criteria describe the depositional habitat of MISS occurrence as follows. MISS occur in rocks of not more than low-grade metamorphosis. In stratigraphic sections, MISS occur at turning points of 
regression-transgression. MISS occur in the depositional "microbial mat facies." The distribution pattern of MISS reflects the average hydraulic pattern in a depositional area. The last three criteria describe the MISS themselves as follows. The fossil MISS resemble strongly or are identical with geometries and dimensions to modern ones. The MISS include microtextures that represent, or were caused by, or are related to, ancient biofilms and microbial mats. Geochemical analyses support the interpretation as MISS.

Using this set of criteria, more than 14 studies have systematically explored MISS from modern to ancient sites, comparing structures in equivalent environmental settings from the modern right back to the early Archean (e.g., Noffke 1999, 2000; Noffke and Krumbein, 1999; Noffke et al., 2001a, 2002, 2003, 2006a, 2006b, 2008). This suite of studies has assembled a data set that enables the evolution of MISSprokaryota to be monitored throughout Earth's geological record. The investigation of MISS is divided into four steps: (i) detection, (ii) identification, (iii) confirmation, and (iv) differentiation (Noffke, 2010). (i) Detection is the visual reconnaissance during a geological survey of candidate sediments and sedimentary rocks. (ii) A candidate structure (e.g., for erosional remnants and pockets) is measured with respect to geometry and dimension, and indices such as the MOD-I (modification index) are determined (see later in this article).
The assembled data that have arisen from these systematic studies now allow the quantitative comparison of any candidate structure with other MISS from other periods in Earth history including the modern. (iii) Analyses on the mineralogy and geochemistry of the candidate structure are conducted (e.g., presence of carbon in laminae). (iv) A comparison with similar but abiotic phenomena is made, if any similar but abiotic phenomena exist. As demonstrated, this set of biogenicity criteria compiles various lines of evidence and allows for identification of fossil structures with a high probability. This study on possible MISS in the Dresser Formation employs this methodological approach as well.

Microbially induced sedimentary structures are listed as one target for the Mars Exploration Rover Program (Committee on an Astrobiology Strategy for the Exploration of Mars, 2007). On Mars, sabkha settings are well known, where sedimentary surface structures and rock beds record the former existence of fluid water (e.g., Grotzinger et al., 2005; Metz et al., 2009). Because of the similarity of the early history of Earth and the early history of Mars, the knowledge on the sabkha habitats of MISS and the criteria of biogenicity of MISS may assist in the exploration of Mars.

To date, the oldest microbial mat communities that formed MISS are from the 3.2 Ga Moodies Group, South Africa (Noffke et al., 2006b; Heubeck, 2009). Here, two
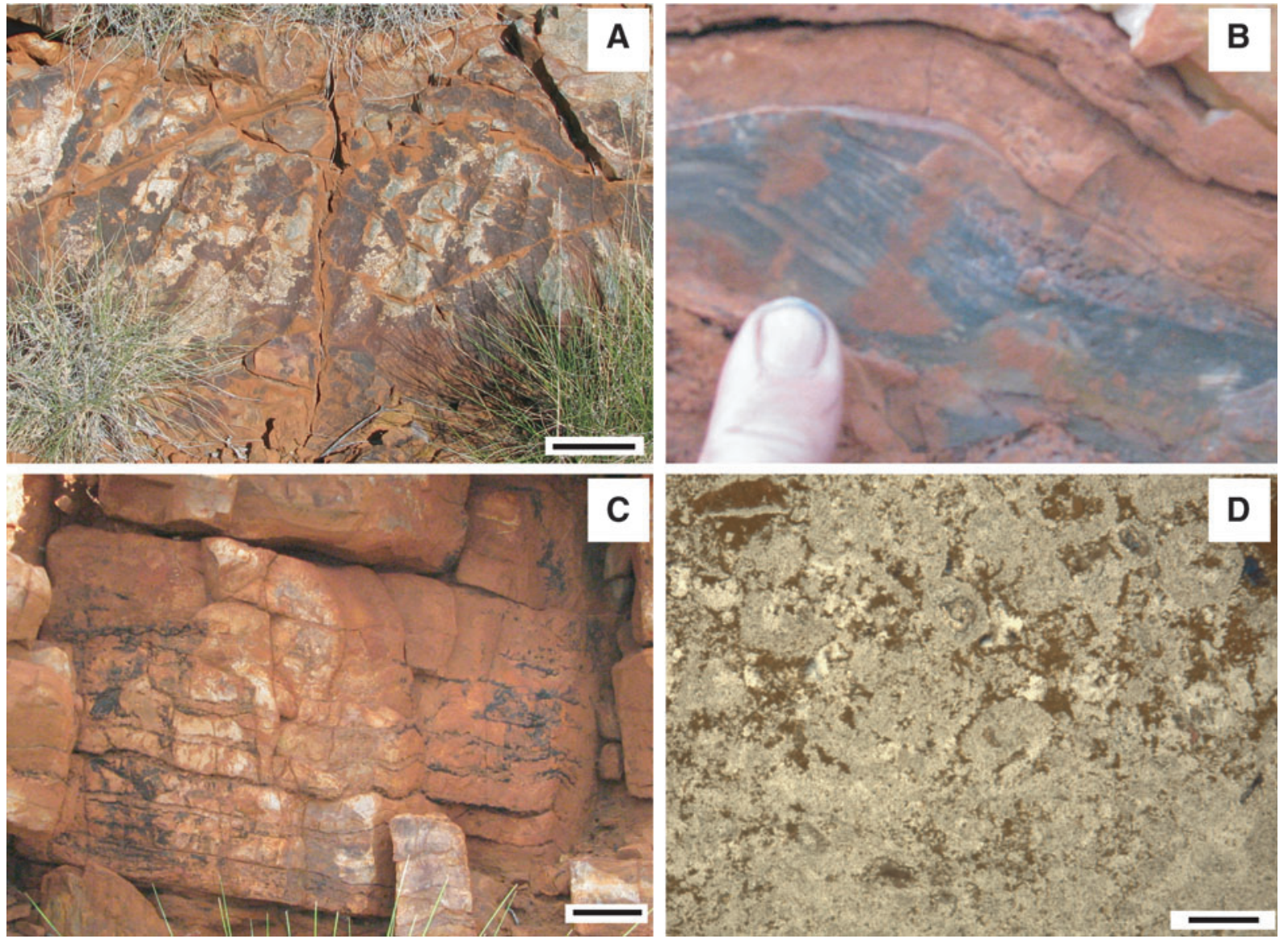

FIG. 4. Sedimentary structures typical in the Dresser Formation, Pilbara, Western Australia. (A) Wave ripple marks on a bed surface tilted about $30^{\circ}$ toward the observer. Scale: $10 \mathrm{~cm}$. (B) Ripple cross stratification in vertical section of a rock bed. Note dark laminae, of which examples are magnified in Fig. 5. (C) Tidalites forming a vertical stack of layers. Scale: $0.5 \mathrm{~cm}$. (D) Oncoids in thin section. Scale: $0.25 \mathrm{~mm}$. 
wrinkle structures and one roll-up structure were detected in tidal deposits. The 2.9 Ga Ntombe Formation, Pongola Supergroup, South Africa, includes eight wrinkle structures that record fossil microbial mats on shallow shelf settings (Noffke et al., 2003). The isochronous shelf of the Brixton Formation of the Witwatersrand Supergroup shows 28 wrinkle structures, two sedimentary surfaces yielding erosional remnants and pockets, and one bedding plane with polygonal oscillation cracks (Noffke et al., 2006a). In thin sections from all study sites, textures are visible that resemble degraded microbial mat fabrics. Cyanobacteria have been suggested to be the constructing agents; however, no unambiguous evidence has been documented (see discussions in Noffke et al., 2003, 2006a, 2006b). Highly diverse microbial mat ecosystems from ancient tidal and sabkha environments are recorded by MISS in the 2.9 Ga Pongola Supergroup, South Africa (Noffke et al., 2003, 2008). Of significance is that these ancient MISS resemble strongly the MISS in equivalent modern settings. Because modern MISS allow the detailed quantification of the hydraulic and sediment-dynamic interaction with biofilms, the gained information assists in the interpretation of ancient MISS, the environment they are situated in, and prokaryote evolution. This similarity of MISS over 3 billion years of Earth history is in contrast to stromatolites, where many early Archean species are unlike the modern ones (Noffke and Awramik, 2013).

The objective of this study was to take the comparative investigation one step further and search for MISS in rocks older than $3.2 \mathrm{Ga}$. This contribution describes a series of distinct types of macrostructures and microstructures from sedimentary rocks of the $c a$. 3.48 Ga Dresser Formation.

\section{The Dresser Formation, Pilbara, Western Australia}

The Dresser Formation is located in the East Pilbara granite greenstone terrane, Western Australia (Fig. 2a). It was chosen for this study because it contains some of Earth's oldest and best-preserved volcanic and sedimentary rocks (Fig. 2b; Barley et al., 1979; Hickman, 2012). The age of this rock succession is determined as $3.481 \pm 3.5$ Ga [Australian Stratigraphic Units Database (2012), Dresser Formation, Stratigraphic Number 36957]. The formation is geographically restricted to a ca. $25 \mathrm{~km}^{2}$ area in the North Pole Dome and consists of bedded chert, carbonate, and siliciclastics, plus pillow basalt and dolerite (Van Kranendonk et al., 2008). The sedimentary rocks were originally micritic carbonates

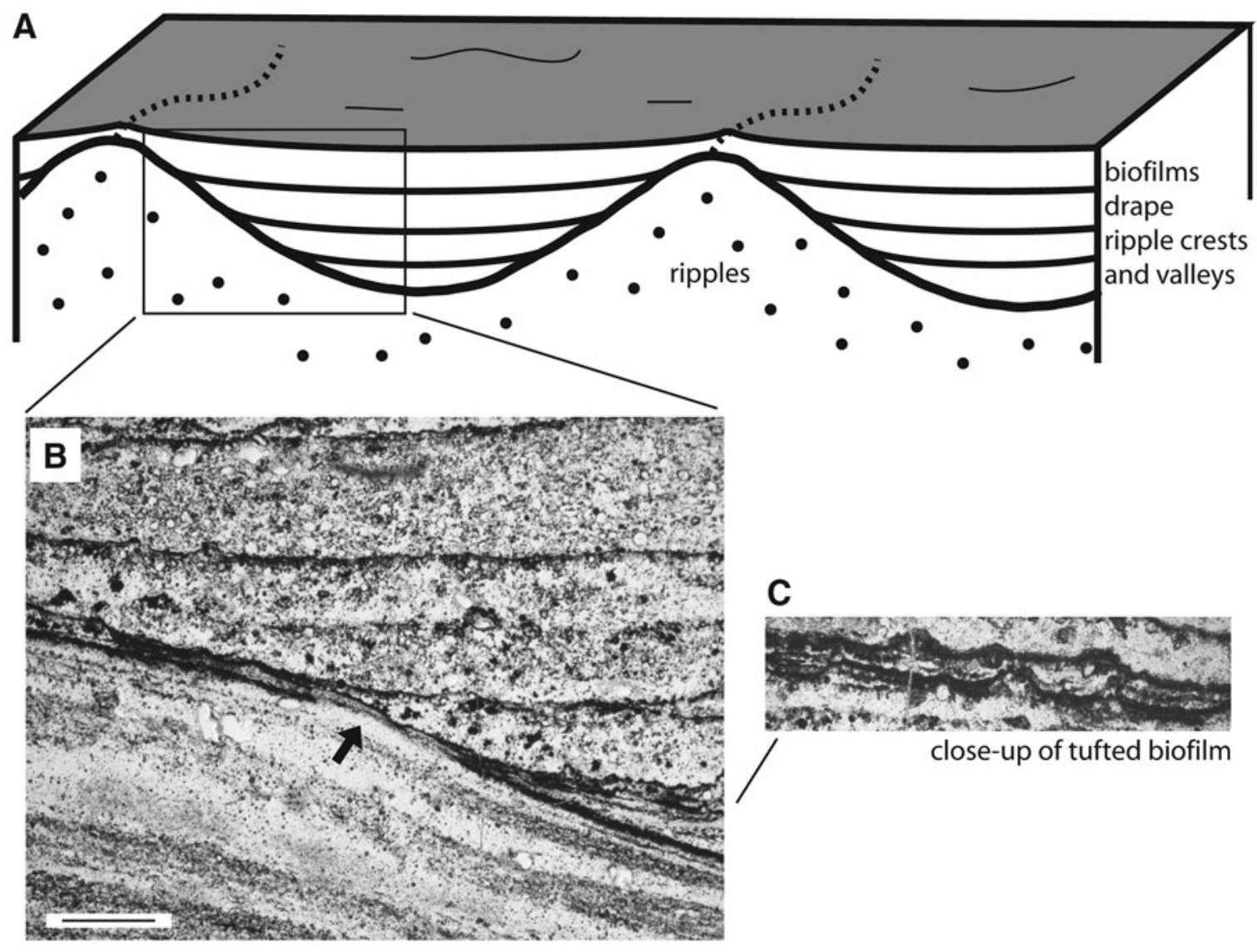

FIG. 5. Crinkled laminae and tufts in microscopic view (thin sections), subtidal zone, 3.48 Ga Dresser Formation, Pilbara, Western Australia. (A) Sketch to point out the situation of the thin section displayed in (B). The thin section shows an area of a vertical cut through ripple marks with their ripple valleys being filled in by sediment. The selected area covers one slope of a ripple mark and about half the ripple valley. Compare this photo also with Fig. 1A. (B) Thin-section view of the area shown in (A). The slope of the ripple mark is draped by a dark lamina (arrow); the horizontal sediment layers that fill in the ripple valley are each covered by a dark lamina as well. Scale: $0.1 \mathrm{~cm}$. Note that none of the dark laminae show any mark of erosion. (C) In close-up the dark laminae include tufted microstructures (compare with modern structure in Fig. 1D; geochemistry of fossil example is shown in Fig. 6). Scale: $50 \mu \mathrm{m}$. 
and evaporites deposited under shallow-water, low-energy (sabkha-type) conditions, interbedded with sandstone and conglomerate deposited during periods of growth faulting and tectonic activity (Lambert et al., 1978; Buick and Dunlop, 1990; Van Kranendonk, 2006; Van Kranendonk et al., 2008). Repeated episodes of growth faulting associated with volcanic activity during carbonate-evaporite sedimentation permitted circulation of hydrothermal fluids that overprinted much of the original sedimentary mineralogy. Carbonate, organic matter, and gypsum were largely replaced by pyrite, hematite, barite, and silica (Van Kranendonk, 2006; Van Kranendonk et al., 2008).

In the Gibson and Great Victoria deserts in central Australia and in the Carnarvon Basin at the west coast Eocene to Oligocene, weathering is common (van der Graff, 1983). Here, the Tertiary tropical climate induced the formation of a soil catena, composed of blocky silcrete at the modern topographic heights, and deep red, silty laterite in topographic lows. Typical structures in the otherwise unconsolidated soils include irregular and steep-sloped cones up to $35 \mathrm{~cm}$ in height, pisolites from 0.5 to $5 \mathrm{~cm}$ in diameter, and karst pipes that facilitate subsurface water flow. However, none of these soil structures were observed in our North Pole study location. Quite to the contrary, the sedimentary rocks in the Dresser Formation are highly consolidated. Stromatolites, ripple marks, ripple cross beds, and other primary sedimentary structures are well preserved and do not display disturbance by any deep soil or silcrete formation.

In addition to the macroscopic phenomena, widespread evidence also remains for the primary mineralogy of the ancient sediments, including relic carbonate rhombs and rhombic voids in silica (Lambert et al., 1978), patches of

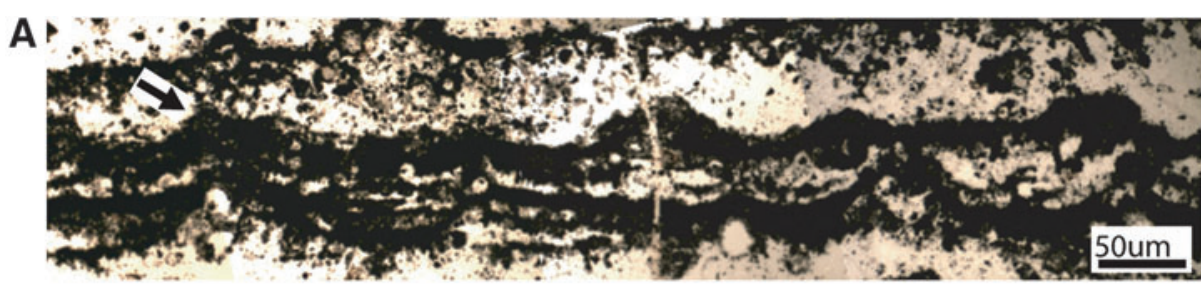

B
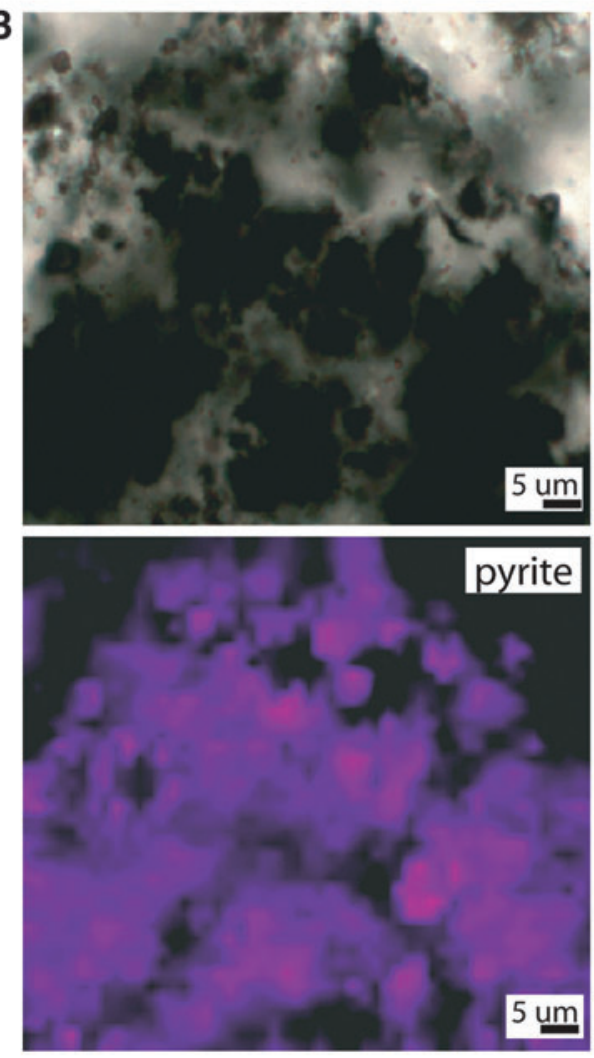

C
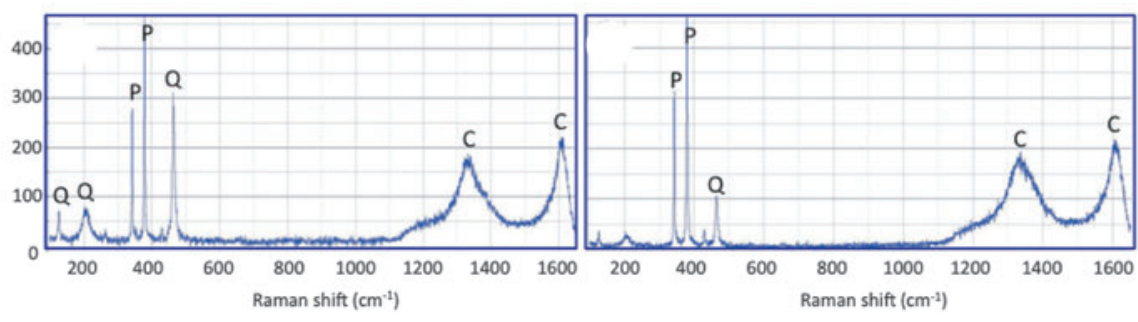

FIG. 6. Tufted microstructures of the subtidal zone, $3.48 \mathrm{Ga}$ Dresser Formation, Pilbara, Western Australia. (A) Thin section photomicrograph taken perpendicular to bedding showing a series of linked tufts. Arrow indicates the tuft analyzed in (BC). (B) Optical image plus Raman chemical maps of a single tuft showing that the tuft is composed of quartz, pyrite, and significant amounts of carbonaceous matter. (C) Typical Raman spectra from two carbonaceous areas of the tuft show the presence of pyrite (P) and quartz (Q) plus two carbon peaks (C) at $\sim 1350 \mathrm{~cm}^{-1}$ (the "D1" disordered peak) and $\sim 1600 \mathrm{~cm}^{-1}$ (the "G" graphite peak). The D1 and $G$ peak positions and widths, plus the D1/G peak heights and areas, are characteristic of thermally mature but disordered organic carbon that has experienced prehnite-pumpellyite to greenschist facies metamorphism (Beyssac et al., 2002). This degree of maturation is consistent with the known metamorphic grade of the Dresser Formation (Van Kranendonk et al., 2008) and indicates that the carbon is probably indigenous to these rocks. 
dolomitic chert in surface outcrop (Walter et al., 1980), peloidal and oncolitic grains (Buick and Dunlop, 1990), extensive carbonate in unweathered drill core material (Van Kranendonk et al., 2008), and observations in this current study of carbonate in many of our thin sections.

\section{Methods of Investigation in the Field and Laboratory}

Geological mapping, millimeter-scale sedimentological stratigraphic logging, and quantitative analysis of morphologies of sedimentary macrostructures were undertaken in the North Pole Dome, Pilbara, Western Australia, in June 2011. Petrological and mineralogical analyses were conducted on standard geological thin sections and polished rock chips. We used the equipment at Old Dominion University, including Olympus BX51 and Olympus SZX12 mi- croscopes equipped with Q Colour 3 Olympus digital cameras. Raman analyses were carried out at the University of Bergen with a Horiba LabRAM HR800 integrated confocal Raman system and LabSpec5 acquisition and analysis software. For Raman, samples were standard uncovered geological thin sections that allowed optical and chemical maps to be superimposed. The laser was focused $\sim 2 \mu \mathrm{m}$ below the surface of the thin sections to avoid surface polishing effects (Fries and Steele, 2011). Since the thin sections were $\sim 30 \mu \mathrm{m}$ thick, there was no possibility of obtaining a Raman signal from the mounting resin. All analyses were carried out by using a $514.5 \mathrm{~nm}$ laser, $100 \mu \mathrm{m}$ confocal hole, $1800 \mathrm{~mm} /$ line grating, and $\times 50$ objective lens. Dual acquisitions were taken from each analysis point, each with an acquisition time of $4 \mathrm{~s}$. Maps were acquired with a $1.5 \mu \mathrm{m}$ spatial resolution by using selected peaks from the Raman spectra.
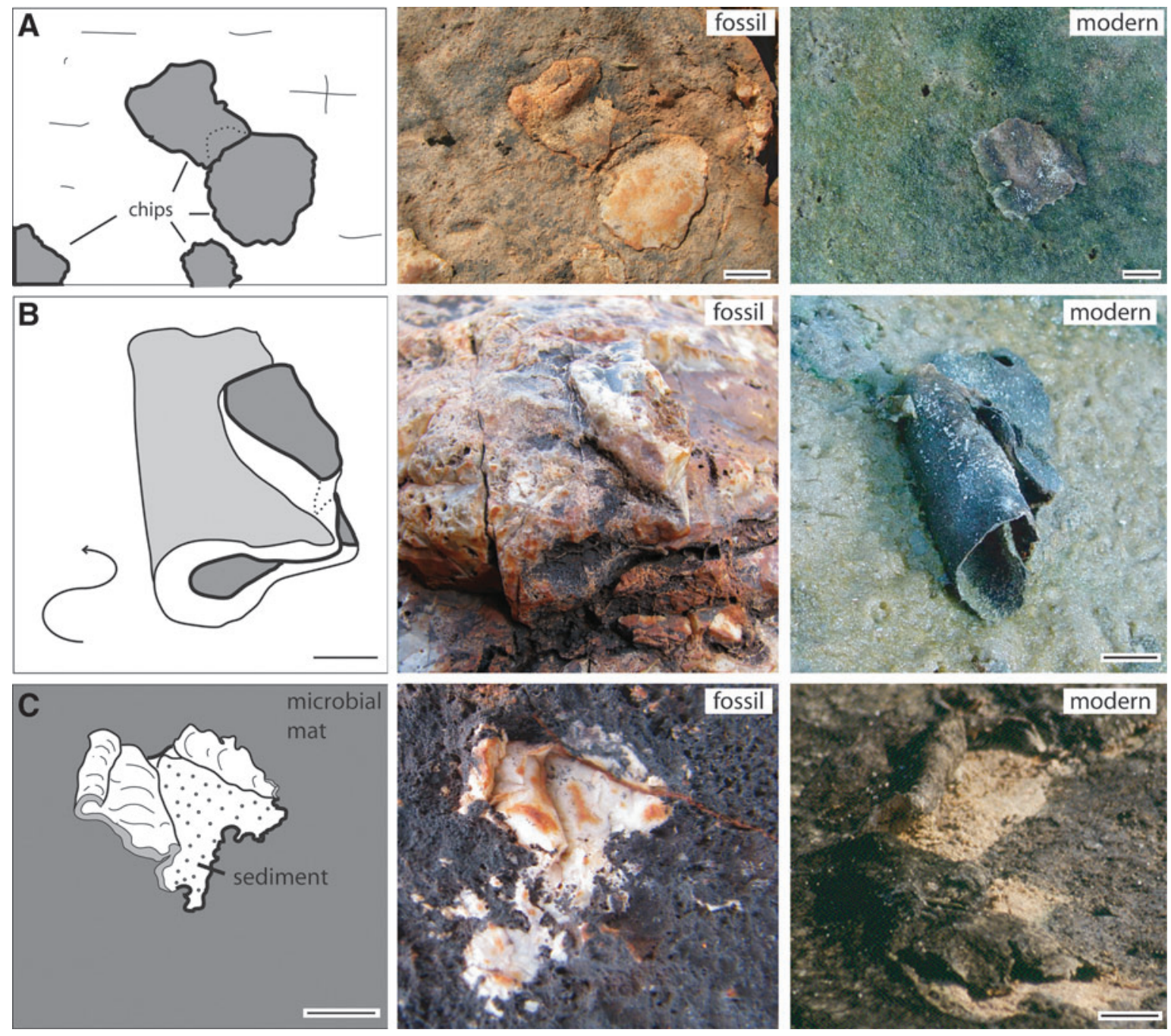

FIG. 7. Macrostructures of the intertidal zone, 3.48 Ga Dresser Formation, Pilbara, Western Australia, plus possible modern equivalents. The center images show the Dresser Formation structures; for better visualization, the Dresser structures are outlined in the sketches on the left. The right images show possible modern counterparts of such structures. (A) Flat fragments deposited at random on the sedimentary surface in the Dresser intertidal flats. In equivalent modern settings, such fragments represent microbial mat chips; example from Portsmouth Island, USA. Such chips were ripped off their parent site along fringed edges of microbial mats, similar to those shown in the insert of Fig. 1B. (B) Rolled-up fragment. In modern settings, microbial mat chips can be rolled up in this fashion by currents or by desiccation; example from Portsmouth Island, USA. (C) upward-bent, dark-colored sediment lamina. In modern environments, such laminae represent microbial mats separated from their substrate by erosion; example from El Bibane, Tunisia. All scales: $1 \mathrm{~cm}$. 


\section{Description of Sedimentary Structures in Ancient Coastal Sabkha Settings of the Dresser Formation and Discussion of Their Possible Biogenicity}

Seven stratigraphic sections were analyzed at millimeterscale resolution, covering a total stratigraphic thickness of $39.8 \mathrm{~m}$ (locations shown in Fig. 2c; detailed profiles in Fig. $3 a-3 h)$. The lithology and sedimentary structures record an ancient coastal sabkha in which a subtidal zone, an intertidal zone, a lower supratidal zone, a lagoon, and a barrier were distinguished. Our observations are in line with those of Buick and Dunlop (1990), who described the paleoenvironment of the entire Dresser Formation in detail. In the present time, sabkhas are colonized by ubiquitous microbial mats forming MISS.

In the following, we describe the fossil sedimentary structures of the Dresser Formation and discuss the possibility of biological origin by comparing them with the modern MISS in equivalent sabkha settings. The fossil sedimentary structures form discrete morphologies that display sharp transitions with their surroundings. The structures do not resemble cones, pisolites, or vertical pipes caused by any weathering and soil-forming processes currently known.

\subsection{The subtidal zone}

4.1.1. Description. Wave ripple marks of about $8 \mathrm{~cm}$ crest to crest amplitudes and occasional, small-scale crossstratification of climbing ripples record an ancient subtidal area (Fig. 4a). Two rock beds included ripple cross stratification lined by dark laminae (Fig. 4b). In vertical thin sections, the slopes and valleys of ripple marks are draped by slightly crinkled, dark-colored laminae (Fig. 5). In close-up, the laminae are spotted by tufts that all have a similar height/base ratio of $10 / 50$ to $25 / 75 \mu \mathrm{m}$, arranged at regular distances of 100-125 $\mu \mathrm{m}$ from each other (Fig. 6a). Raman analysis showed that the crinkled laminae and tufts are mostly composed of pyrite plus small amounts of relic carbonaceous material (Fig. 6b and 6c), within a silica-rich matrix. This composition is consistent with syndepositional replacement of carbonaceous laminae by pyrite and later replacement of carbonate by silica.

4.1.2. Interpretation. Similar ripple structures and biofilm textures are known from modern subtidal areas. The structures, visible in vertical section through cores of fresh sediment, are called "sinoidal structures" (Fig. 1a) (Noffke
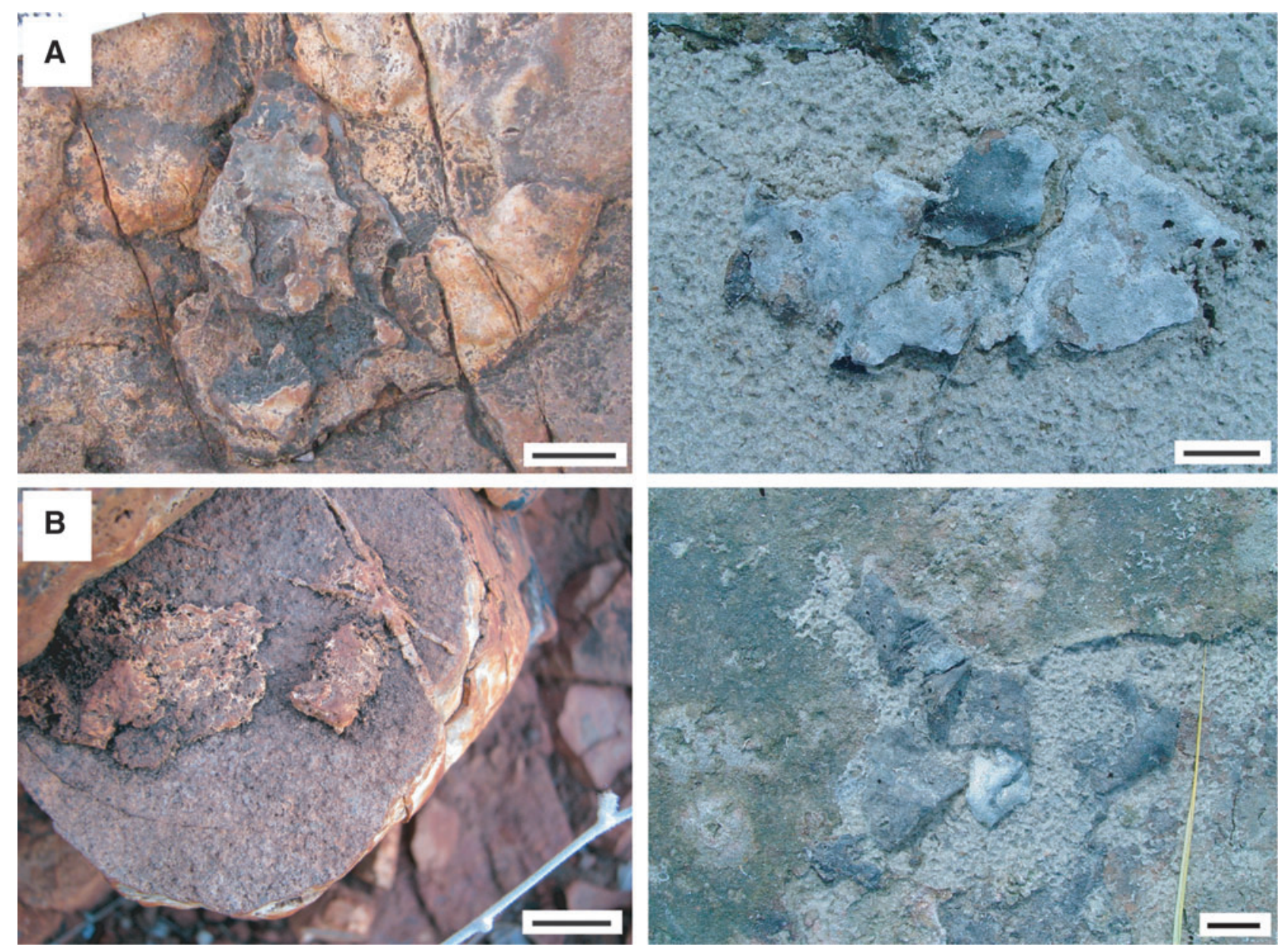

FIG. 8. Fragments accumulated as piles in the intertidal zone, 3.48 Ga Dresser Formation, Pilbara, Western Australia, plus possible modern equivalents. (A) Left: fossil fragments. Right: In the modern intertidal zone of Portsmouth Island, USA, microbial mat chips were accumulated by water currents. (B) Left: Three fragments are accumulated as a pile; two fragments were deposited individually; Dresser Formation. Right: a similar situation in the modern intertidal zone of Portsmouth Island, USA. All scales: $1 \mathrm{~cm}$. 

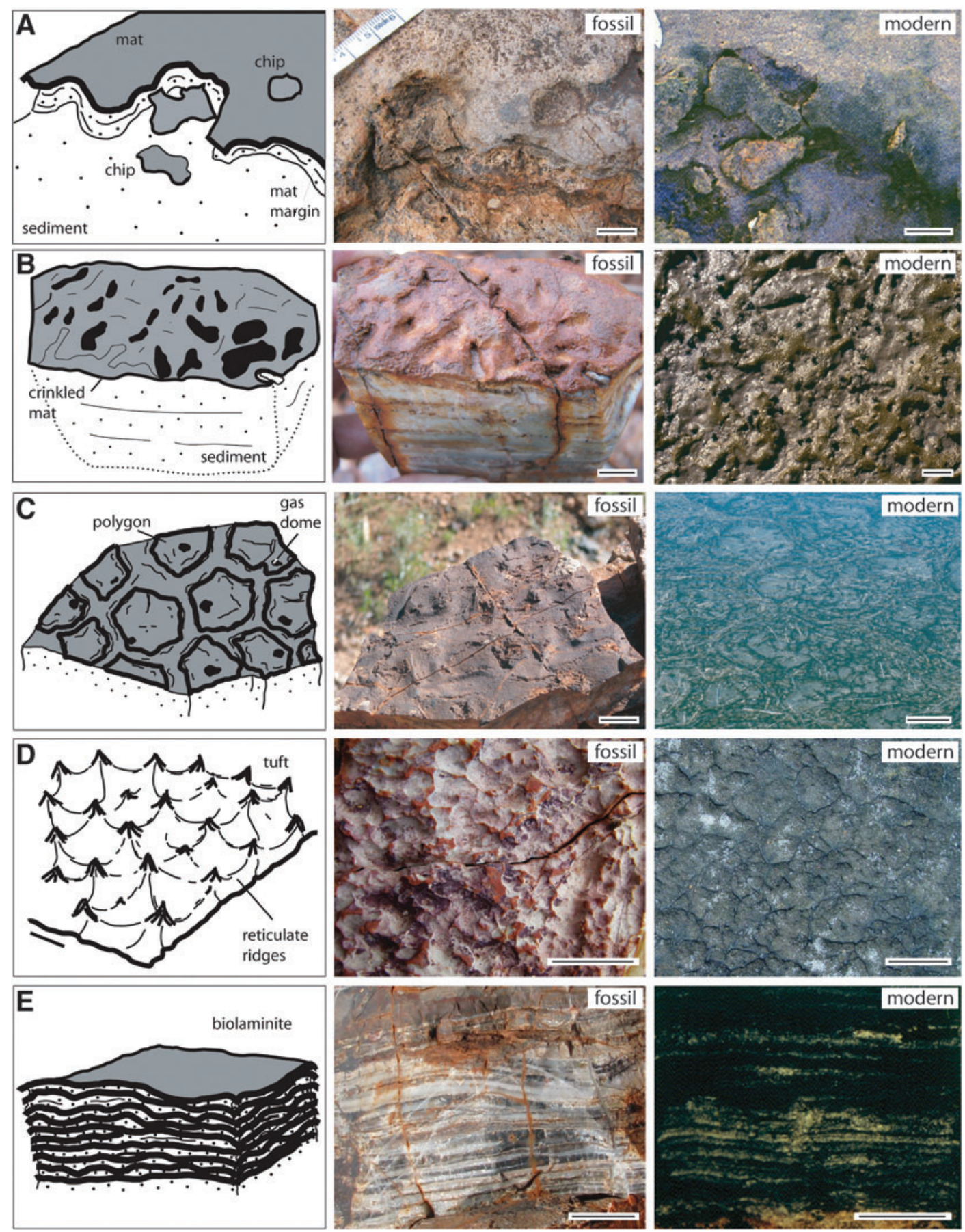

FIG. 9. Macrostructures of the lower supratidal zone, 3.48 Ga Dresser Formation, Pilbara, Western Australia, plus possible modern equivalents. The center images show the Dresser Formation structures; for better visualization, the Dresser structures are outlined in the sketches on the left. The right images show possible modern counterparts of such structures. (A) Fragments deposited along the edge of an erosive margin. One fragment is deposited on top of the elevated, planar surface of the eroded margin; the other fragment is situated close to its original parent site at the edge of the erosive margin. In modern settings, such erosive margins with irregular edges are caused by partial erosion of microbial mat-stabilized surfaces (compare the example shown in the insert of Fig. 1B). The irregular shape of the fossil fragments supports the interpretation as a possible mat chip. Note that the microbial mat-covered sediment is elevated (=erosional remnant). In contrast, sediment bare of microbenthos is deeper lying (= erosional pocket; compare with Fig. 10); modern example from Mellum Island, Germany. Scale: $1 \mathrm{~cm}$. (B) Wrinkled upper surface of a rock bed. In modern environments, such wrinkle structures are typical for surfaces of EPS-rich microbial mats; modern example from Mellum Island, Germany. Scale: $1 \mathrm{~cm}$. (C) Sedimentary rock surface arranged into polygons. Many polygons have a hole in their center. In modern settings, such polygons form within microbial mats exposed to seasonal changes of humidity. They are called polygonal oscillation cracks. Each individual polygon is separated from its neighbors by a 3-10 cm wide transition zone (desiccation cracks, often overgrown by a younger generation of microbial mat). The holes in each of the polygons are collapsed gas domes (compare Figs. 1C and 14); modern example from El Bibane, Tunisia. Scale: $10 \mathrm{~cm}$. (D) Honeycomb pattern of ridges and tufts exposed on a surface of a sedimentary rock bed. In modern settings, such ridges arranged into a honeycomb pattern are typical for microbial mats developing in tidal pools. Meeting points of ridges are marked by tufts; example from Portsmouth Island, USA. Scale: $5 \mathrm{~cm}$. (Compare Fig. 1D.) (E) Dark-light laminae forming a stack in possibly lagoonal sedimentary rocks. In modern settings, such laminae become visible in vertical section through very mature microbial mats. The laminae represent many layers of succeeding microbial mat generations, or microbial mat-overgrown lagoon sediments. Stacks of mat laminae are called biolaminites. Millimeter-scale mat chips and roll-ups occur within laminae (compare Fig. 17, geochemistry in Fig. 18); modern example from El Bibane, Tunisia. Scale: $5 \mathrm{~cm}$. 
et al., 2001b). Sinoidal structures are ripple marks overgrown by microbial mats so that the ripple mark relief appears smoothed. The ripple valleys are filled in by laminae of microbial mat, often alternating with sediment layers similar to these shown in Fig. 5. In the fossil example of the Dresser Formation, the ripple valleys with their biofilm-covered sediment infills are evident. The ripple slope was biostabilized by a cover of biofilm before sediment was subsequently deposited in the ripple valleys. The deposition of the valley sediments took place in increments, interrupted by periods of non-sedimentation during which biofilms would develop on the ripple valley infill (Gerdes and Krumbein, 1987). During the subsequent deposition of sediment, the proceeding biofilm cover was not eroded. This preservation is visible along the unaffected slope of the ripple mark as well as along the individual mat-covered surfaces of the infilling sediment (Fig. 5). Mud layers would not have resisted the deposition of subsequent sediment and also would not include tufts. The arrangement of tufts and their sizes are too regular to be a consequence of fine sediment that was pushed up locally by sediment grains projecting from the sedimentary surface. Furthermore, the mineralogical composition of the dark laminae contradicts any interpretation as being of abiotic sedimentary origin.

The Dresser Formation subtidal zone also includes stromatolites, which have been described in earlier studies (e.g., Buick and Dunlop, 1990; Van Kranendonk, 2006; Van Kranendonk et al., 2008).
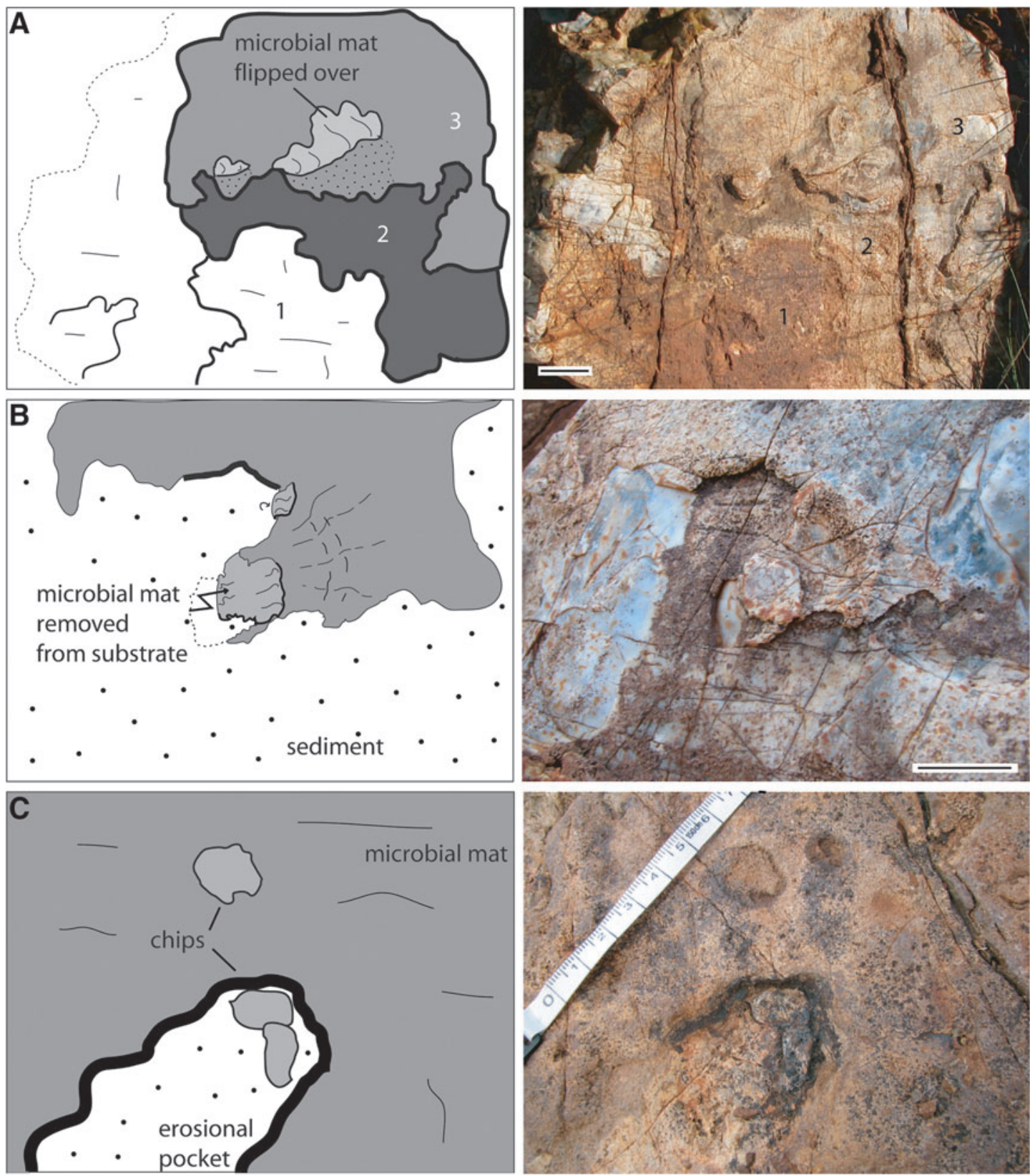

FIG. 10. Macroscopic sedimentary structures of the lower supratidal zone, 3.48 Ga Dresser Formation, Pilbara, Western Australia. (A) Three generations of erosive margins (numbers 1 to 3). Scale: $5 \mathrm{~cm}$. (B) Edge of an erosive margin in close-up. Scale: $5 \mathrm{~cm}$. (C) Fragments deposited in front of an erosive margin. (Compare Figs. 1B and 10A.) Tape for scale. 


\subsection{The intertidal zone}

4.2.1. Description. A narrow intertidal belt along a coast is typically caused by daily micro-tides. Such tidal currents are recorded by alternating bedding of coarse-fine layer couplets. In the Dresser Formation, small $1 \mathrm{~cm}$ scale current ripple marks and $1-2.5 \mathrm{~cm}$ thick sedimentary couplets may be interpreted as of micro-tidal origin. The couplets are stacked together, making a total outcrop between 10 and $40 \mathrm{~cm}$ thick (Fig. 4c). Here, 12 well-exposed bedding surfaces range from $10 \mathrm{~cm}^{2}$ to $6 \mathrm{~m}^{2}$ in size. These ancient intertidal surfaces are littered with fragments of sediment, $1-3.5 \mathrm{~cm}$ in diameter and up to $0.4 \mathrm{~cm}$ thick, that are distinct in appearance compared to the surrounding rock (Fig. 7a); some of these fragments demonstrate flexible behavior and appear to be rolled up (Fig. 7b, 7c, 9a, 10c).

4.2.2. Interpretation. Such centimeter-scale fragments may be interpreted as pieces of microbial mat ("chips"), which were ripped off their parent site, transported, and finally re-deposited on the sedimentary surface (Noffke, 2010). Frequently, such microbial mat chips pile up in the current shadow behind current barriers (Fig. 8). Some chips may roll up due to currents or desiccation. Microbial mat chips have a characteristic shape, which can be quantified by the morphology index of a microbial mat chip. It is described as the ratio between the greatest and smallest diameter of a microbial mat chip. The morphology index of the Dresser mat chips $(1.81 ; n=41)$ closely compares to those of mat chips in the $2.9 \mathrm{Ga}$ Pongola Supergroup $(1.72 ; n=55)$ and modern mat chips from Portsmouth Island, USA (1.75; $n=55)$, whereas simple mud clasts from Portsmouth Island have a much lower index of $1.41(n=50)$.

\subsection{The lower supratidal zone}

4.3.1. Description. Fossil wash-over fans with internal planar lamination record a lower supratidal zone occasionally flooded during landward storms. Here, four $80 \mathrm{~cm}^{2}$ to $1.30 \mathrm{~m}^{2}$ sedimentary surfaces were found that display a peculiar surface morphology: the bedding surfaces are arranged into elevated surface portions and deeper surface portions (Figs. 9a and 10). Crinkled surface portions may occur (Fig. 9b). For each bed, the elevated surface portions have similar heights in relation to the deeper surface portions. The change in topography of the elevated surface areas compared to the deeper areas ranges between 1 and $3 \mathrm{~cm}$; the slope angles that connect the elevated areas with the deeper surface areas are between 15 and 90 degrees.

Fragments, of sizes and shapes similar to those described from the intertidal zone (above), are often seen in the depressed surface areas (Figs. 9a and 10). Thin sections of the fragments from this lower supratidal zone show dark laminae that form a carpetlike network entangling sandsized grains (Fig. 11). The laminae appear diffuse; no discrete outline is preserved. It is therefore difficult to determine the thickness of an individual filament. We estimate that filamentlike textures range from 5 to $20 \mu \mathrm{m}$ in diameter. Raman analysis shows that the laminae are composed of finely clotted hematite and carbonaceous material (Fig. 12).

4.3.2. Interpretation. In modern coastal systems, a large area of sabkha surface is occupied by the lower supratidal zone. Here, erosional remnants and pockets are a very typical sedimentary surface relief (Fig. 1b); the relief is represented by two geometrical elements, as follows: (i) elevated flat-topped surface areas that are overgrown and stabilized by microbial mat and (ii) deeper-lying surface areas where the sediment is exposed (Noffke, 1999, 2010). Erosional remnants and pockets each range in size between some tens of centimeters squared to many meters squared, with the relief morphology defined by the degree of biostabilization by the microbial mat covering the remnants (Noffke and Krumbein, 1999) — the more pronounced the relief, the higher was the degree of biostabilization by the mats and the higher the erosive force by currents. The degree of microbial biostabilization in shaping the sedimentary surface $(\mathrm{N})$ is
FIG. 11. Photomicrograph of thin section perpendicular through fragment, lower supratidal zone, Dresser Formation, Pilbara, Western Australia. Dark laminae (filamentlike textures) form a carpetlike network in which individual sedimentary grains are interwoven. Note the diffuse appearance of each lamina, which allows only a two-dimensional interpretative sketch. Scale: $500 \mu \mathrm{m}$. Color images available online at www.liebertonline.com/ast

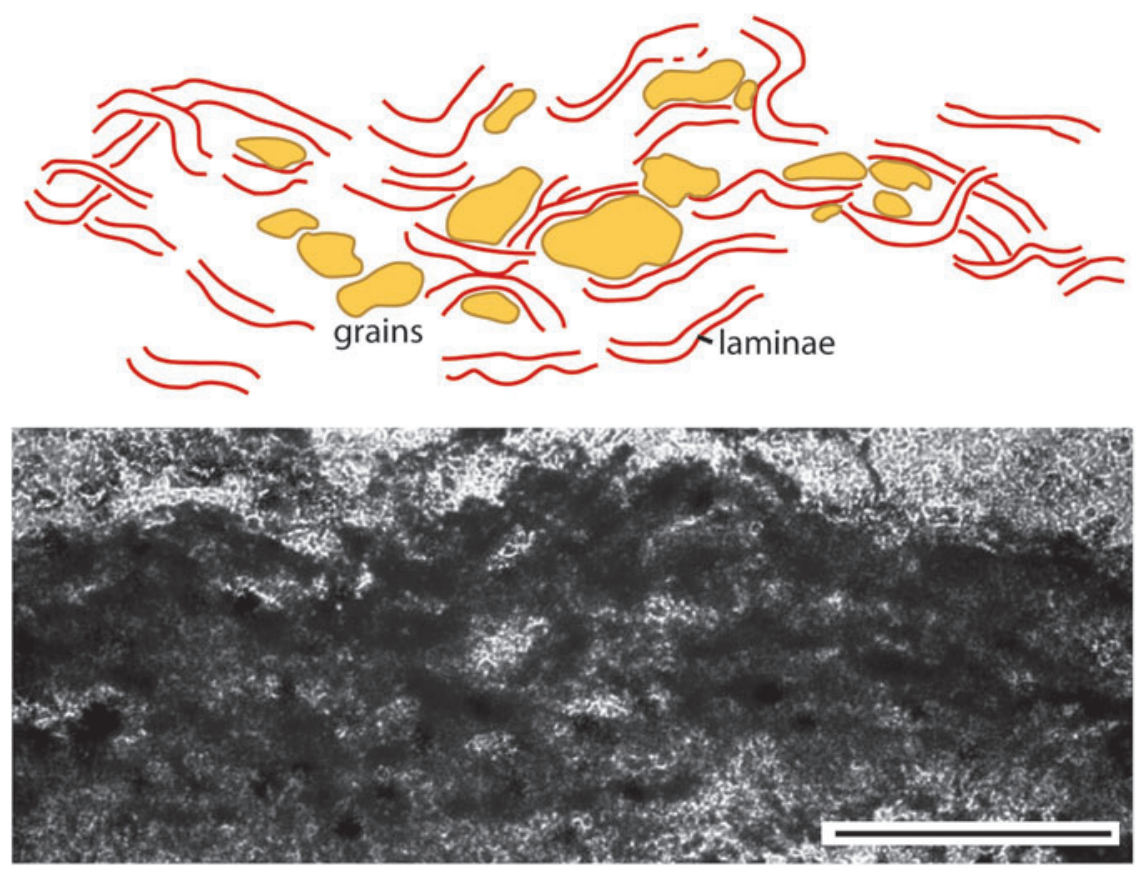



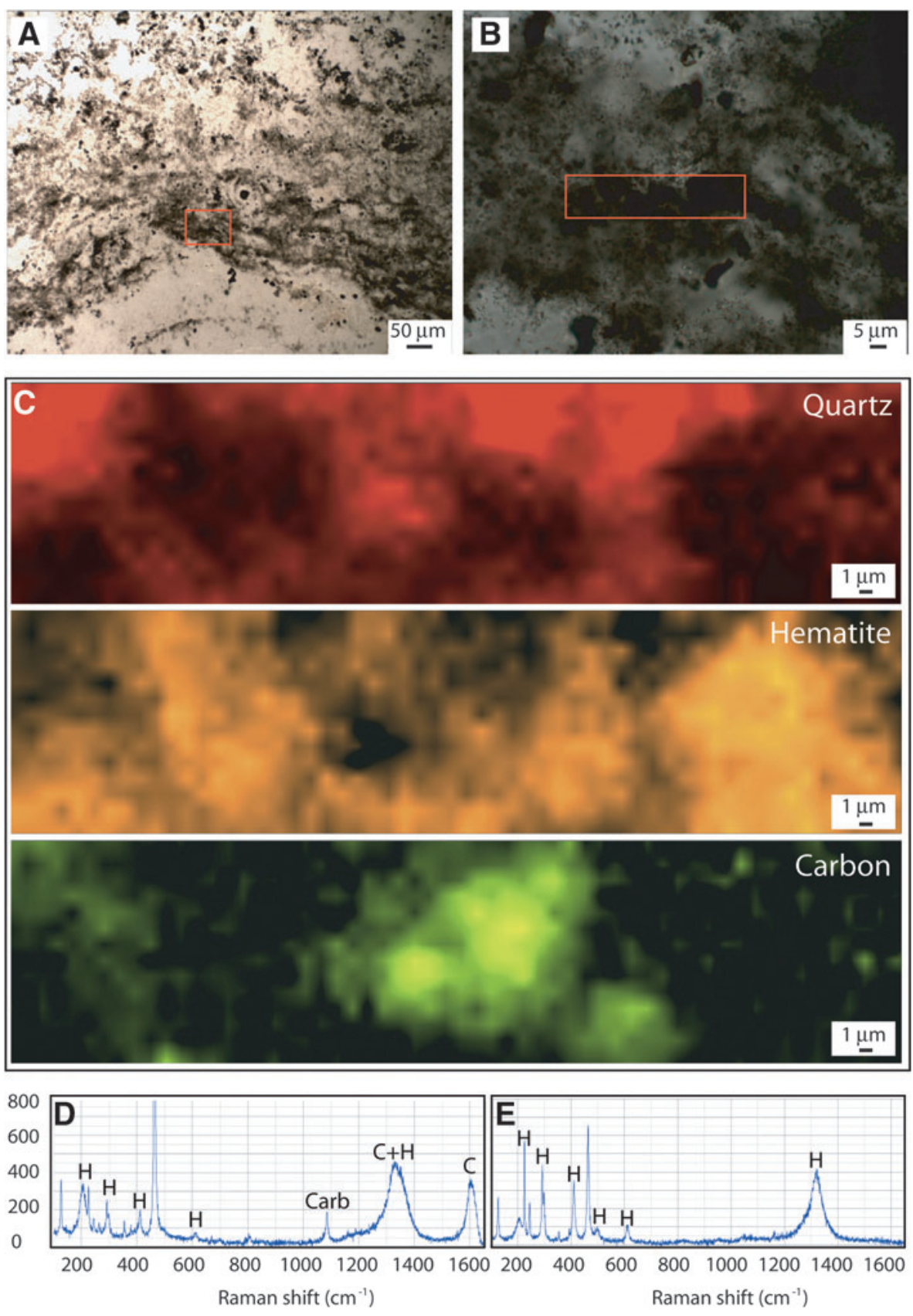

FIG. 12. Morphology and geochemistry of network of laminae in sediment of the lower supratidal zone, 3.48 Ga Dresser Formation, Pilbara, Western Australia. (A) Thin-section photomicrograph of dark brown laminae forming a carpetlike network (compare to filamentlike textures in Fig. 11); box in $(\mathrm{A})$ is enlarged in (B); boxed area in (B) indicates area analyzed by Raman in (C) to (E). (C) Raman chemical maps of part of filamentous texture showing that it is composed of hematite and organic carbonaceous matter enclosed within a matrix of quartz. The hematite map was produced using the $\sim 415 \mathrm{~cm}^{-1}$ hematite Raman peak, the quartz map using the $\sim 465 \mathrm{~cm}^{-1}$ Raman quartz peak, and the carbon map using the $\sim 1600 \mathrm{~cm}^{-1}$ Raman carbon peak. (D) Raman spectrum from an area of the filamentous texture rich in hematite $(\mathrm{H})$ and carbon $(\mathrm{C})$ showing the typical peaks for each mineral. Note that carbon and hematite both have major peaks in the $1320-1350 \mathrm{~cm}^{-1}$ region, so the presence of organic carbon must be confirmed and mapped using the $1600 \mathrm{~cm}^{-1}$ peak (Rividi et al., 2010; Marshall et al., 2011). Carbonate (labeled "Carb") is occasionally found in the vicinity of these filamentous textures. (E) Raman spectrum from hematite-rich area lacking organic carbon. Note absence of carbon $1600 \mathrm{~cm}^{-1}$ peak. Unlabeled peaks in (D-E) are from the quartz matrix. expressed in the "modification index" (MOD-I) [MOD-I= $\left.\mathrm{I}_{\mathrm{A}} \times \mathrm{I}_{\mathrm{S}} \times \mathrm{I}_{\mathrm{N}}\right]$ (Noffke and Krumbein, 1999). The MOD-I for the description of erosional remnants and pockets is based on three sub-indices: (i) area of mat-covered depositional surface to total area of investigation $\left(\mathrm{I}_{\mathrm{A}}=\mathrm{A}_{\mathrm{m}} / \mathrm{A}_{\mathrm{i}}\right)$, (ii) the angles of slopes of the erosional remnants $\left(I_{S}=\sin \alpha\right)$, and (iii) the degree of planarity of a microbial mat cover $\left(\mathrm{I}_{\mathrm{N}}=1-\left[\left(\mathrm{H}_{\mathrm{p}}-\right.\right.\right.$ $\left.\left.\mathrm{H}_{\mathrm{b}}\right) / \mathrm{H}_{\mathrm{p}}\right]$ ). Planarity is result of mat growth and baffling and trapping of grains. A MOD-I of 0 would represent no microbial influence in the formation of surface relief, whereas a value of 1 would represent a maximum influence.

The erosional remnants and pockets described above are directly comparable to the differentially eroded bedding surfaces seen in the Dresser Formation lower supratidal zone (Figs. 9a and 10); hence the Dresser structures can be interpreted as such MISS. The MOD-I of the four fossil erosional remnant- and pocket-bearing sedimentary surfaces $(0.18$, $0.24,0.3$, and 0.33 ) closely compare to similar erosional remnants and pockets from the Pongola Supergroup (0.35) and from modern settings of Mellum Island, Germany (0.25 and 0.3 ). This comparison provides strong evidence for biological control, because sediment that is not consolidated and stabilized by biology does not show such a steep surface relief, and MOD-I approaches zero. In areas where microbial mats diminish by the end of the growth season, the erosional remnant and pocket relief will dissolve (Noffke and Krumbein, 1999). Hence, abiotic erosional remnants and pockets are not known to exist. Sediment grains in a network of laminae likely indicate syndepositional trapping and binding of the grains by a microbial mat. Younger Archean and modern examples of microbial mat textures show such a matrix as well (Fig. 13). 

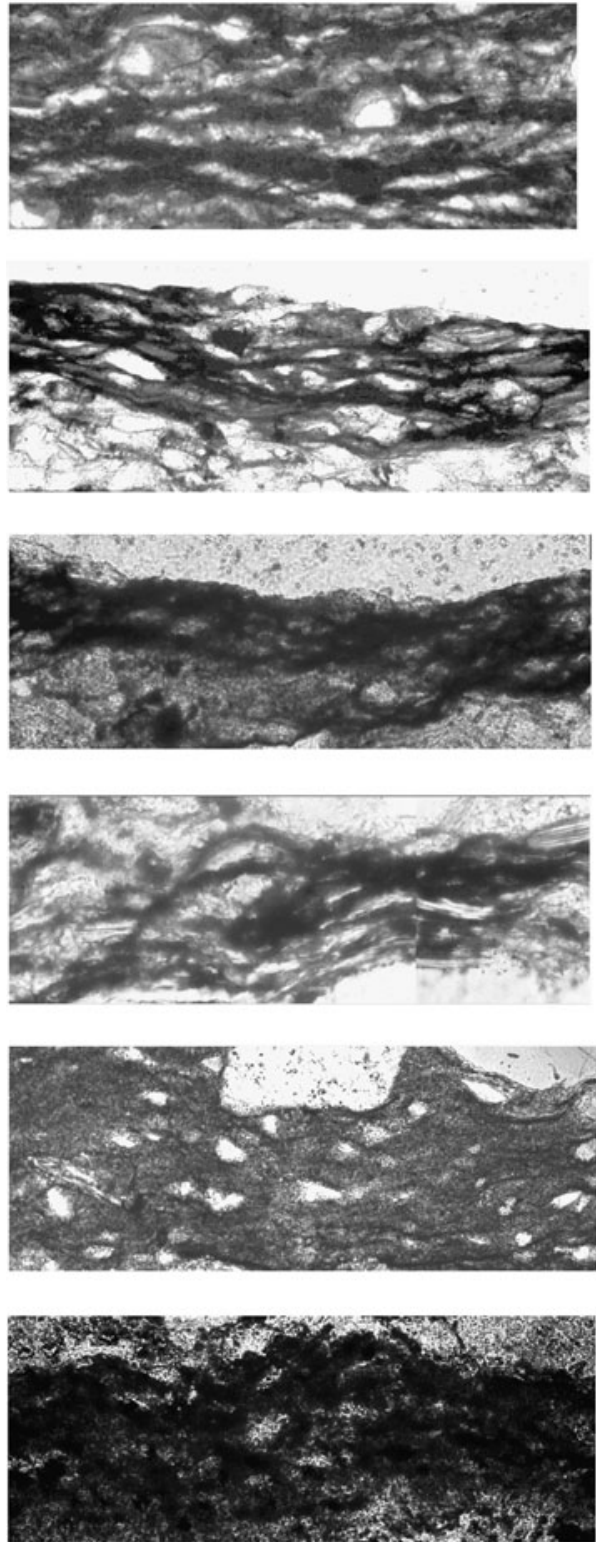

2.9 Ga Mozaan Group

3.2 Ga Moodies Fm

\subsection{Ga Dresser Fm}

500 um

Gres et Schistes de la Cluse de I'Orb

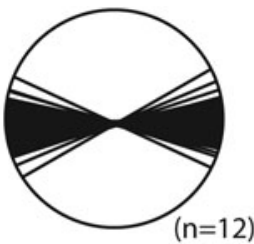

650 Ma Nama Group
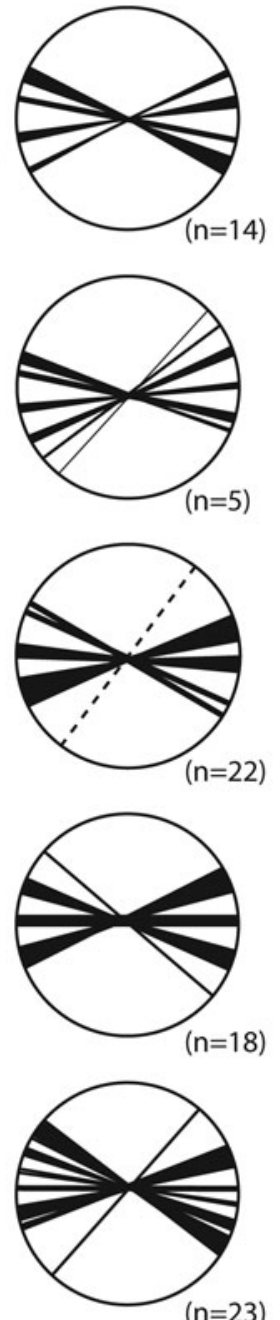

$(n=23)$

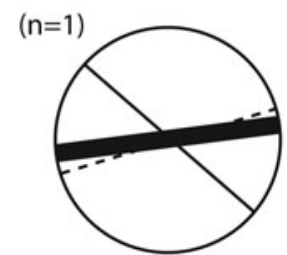

\subsection{Ga Sinqueni Fm}

\section{$\overline{500 \mathrm{um}}$}

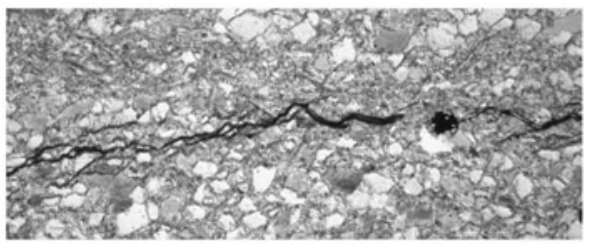

FIG. 13. Laminae forming a network typical for microbial mats as seen in thin sections; Archean, Proterozoic, and Phanerozoic (including modern) examples are compared with each other. On the left side, networks of filamentlike textures (laminae) of various ages are compared with each other, starting at the base with the oldest, the Dresser Formation, and continuing upward with younger examples. On the right, rose diagrams summarize the alignment of laminae defining the networks; note that the networks of all periods of Earth history studied show a very similar dumbbell shaped pattern (right; $\mathrm{n}=$ number of thin sections studied). Also, the thin sections deriving from the Dresser sedimentary rocks display similar network patterns; compare Fig. 12 for their geochemistry. In contrast, abiotic laminae of a stylolite preserved in the 2.9 Ga Pongola Supergroup, South Africa, are shown in the lower portion of the figure. Note that the stylolite resulted in a different alignment pattern of laminae (from Noffke et al., 2008). 


\subsection{The upper supratidal zone}

4.4.1. Description. Four well-preserved bedding surfaces, $90 \mathrm{~cm}^{2}$ to $3.6 \mathrm{~m}^{2}$ in areal extent, display patterns of polygonal cracks (Fig. 9c). The cracks record several perennial shallow ponds within an ancient upper supratidal zone that experienced seasonal periods of desiccation. The polygons are separated from each other by $3-10 \mathrm{~cm}$ wide cracks. The polygons often have fine ridges or bulges along their edges, lining the cracks. Many polygons have a hole close to their center.

At two of these sites in the Dresser Formation, the rock bed surfaces also display fine, reticulate "honeycomb" patterns with $\sim 1 \mathrm{~mm}$ high ridges and up to $\sim 4 \mathrm{~mm}$ high tufts (Fig. $9 \mathrm{~d})$. The reticulate pattern is characterized by several generations of centimeter-scale honeycomb-like compartments. Each subsequent generation of compartment is smaller than the last. The compartments have a maximum dimension ratio of approximately 1:2 and a surface area ratio of 1:4.

4.4.2. Interpretation. In modern coastal sabkhas, seasonal tidal ponds develop that may reach up to $15 \mathrm{~cm}$ in depth. In these ponds, epibenthic microbial mats grow. In response to a semi-arid climate, the mats cause "polygonal oscillation cracks" and "gas domes" (Fig. 1c; Noffke et al., 2001a). Polygonal oscillation cracks are polygon-shaped patches of microbial mat separated from each other by a crack. During seasons of high aridity, the microbial mat surface dries out and cracks into polygon-shaped patches of up to $50 \mathrm{~cm}$ in diameter (Noffke, 2010; Carmona et al., 2011). Each polygon is separated from its neighboring ones by cracks up to $10 \mathrm{~cm}$ wide. During the subsequent season of increased humidity/rainfall, the mat patches expand, and the cracks are closed and sometimes even overgrown by a new mat layer. The mat polygons themselves, however, remain clearly visible. The margins of the individual mat polygons may be slightly thickened because of the polygons shrinking and expanding (oscillating) over the course of time. This oscillation of the polygons causes their margins to curl upward. The center of each polygon may bend up because of gas production by microorganisms colonizing the deeper portions of the microbial mat. At some point, these gas domes erupt due to the increasing pressure. The gas is released, and the ruptured gas dome roof collapses. A hole
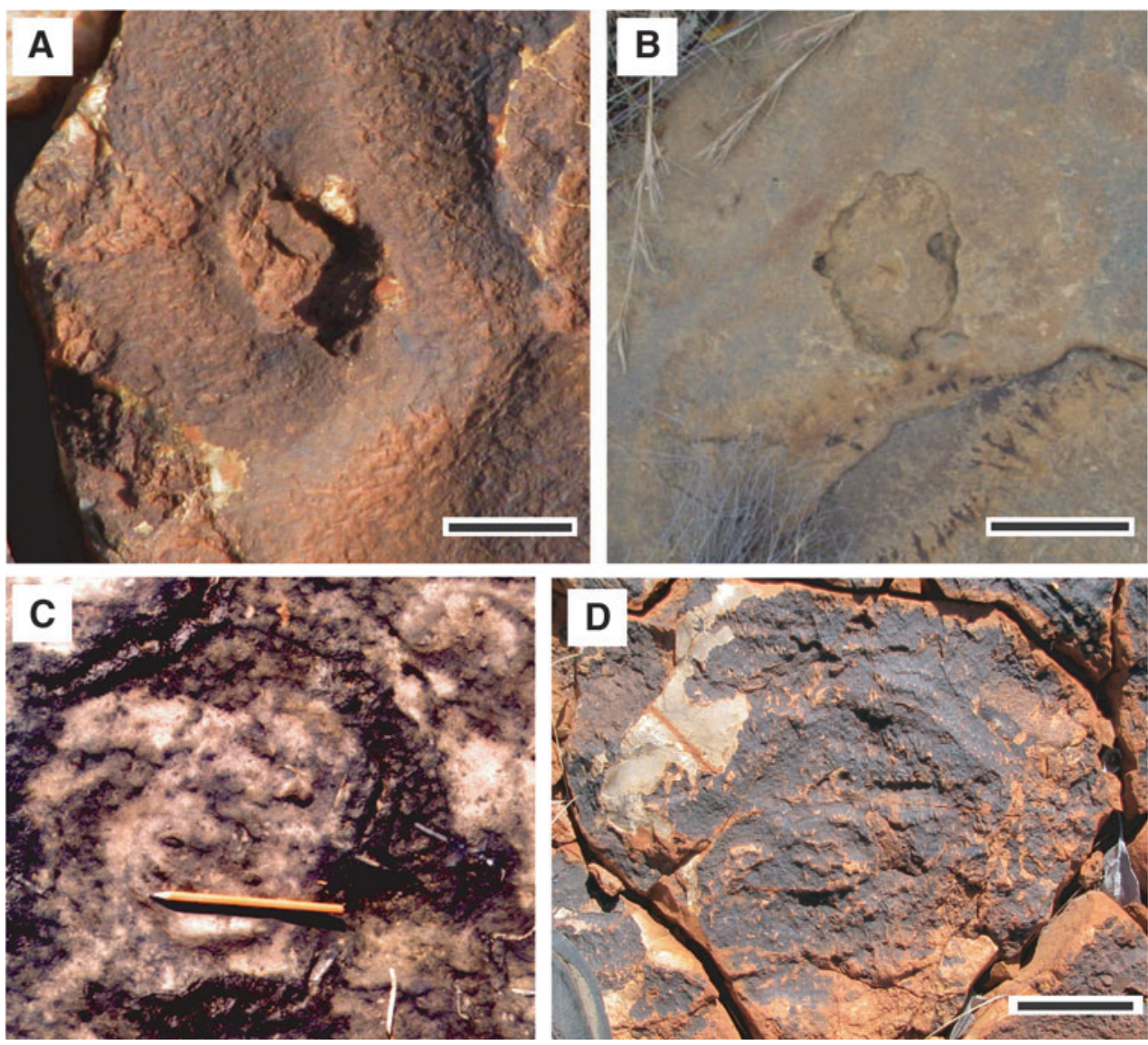

FIG. 14. Polygonal oscillation cracks on sedimentary surfaces viewed from above, fossil and modern examples. (A) This polygon is defined by its slightly elevated margin. The close-up view allows recognition of a fossil gas escape hole in its center; Dresser Formation, Pilbara, Western Australia. Scale: $3 \mathrm{~cm}$. (B) For comparison to (A), this image shows a very similar structure representing an ancient gas escape hole; 2.9 Ga Pongola Supergroup, South Africa. Scale: $5 \mathrm{~cm}$. (C) A single polygon of a microbial mat from the sabkha El Bibane, Tunisia (modern). Note the circularly wrinkled folds within the microbial mat polygon, especially close to the tip of the pen. (D) A single polygon from the Dresser Formation, Pilbara, Western Australia. Note the presence of very similar circularly wrinkled folds. Scale: $4 \mathrm{~cm}$. Compare Fig. $1 \mathrm{C}$ for further modern examples and Fig. 15 for statistical measurements. 


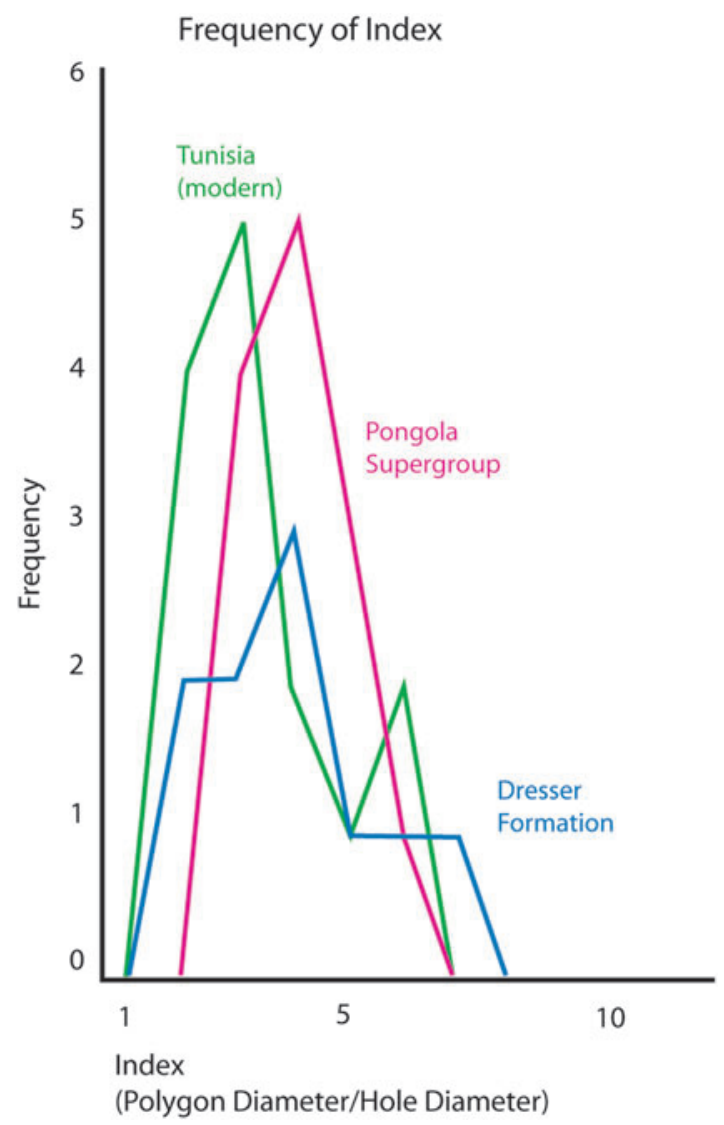

FIG. 15. Comparative morphologies of polygonal oscillation cracks from the $3.48 \mathrm{Ga}$ Dresser Formation, the $2.9 \mathrm{Ga}$ Pongola Supergroup, and El Bibane, Tunisia (modern). The frequency distributions of the polygon diameter/gas hole diameter are similar in all three cases. Dresser Formation polygons are 10 $20 \mathrm{~cm}$ wide, $2.9 \mathrm{Ga}$ Pongola Supergroup examples are 20 $50 \mathrm{~cm}$ wide, and examples from the modern sabkha of Tunisia are $15-50 \mathrm{~cm}$ wide. In the Dresser Formation, the gas escape holes have a diameter of $1-3 \mathrm{~cm}$, and the comparable younger structures show diameters of $3-10 \mathrm{~cm}$, occasionally up to $15 \mathrm{~cm}$. Examples for such structures are shown in Fig. 14 . Color images available online at www.liebertonline.com/ast remains visible in the microbial mat. Other fossil examples of such polygonal oscillation cracks are exceptionally well preserved in the 2.9 Ga Pongola Supergroup, South Africa (Noffke et al., 2008).

Such structures are directly comparable to the cracks and polygons containing central holes and marginal ridges observed in the upper supratidal zone of the Dresser Formation (Figs. 9c and 14); hence the Dresser structures can be interpreted as microbially induced polygonal oscillation cracks and gas domes. Some polygons exposed in the Dresser rocks show circular patterns of wrinkled folds, which suggest the presence of a formerly ductile matrix, a microbial mat, Fig. 14. Frequency distributions of polygon diameter divided by gas escape hole diameter of the Dresser mats match those from younger fossil and modern examples (Fig. 15). The relation of diameters of polygons to diameters of gas escape holes resembles all modern and fossil examples. That is, all ductile material (microbial mats) reacted in the same fashion.

Many of the modern microbial mats in ponds show a reticulate pattern of ridges and tufts at their surface (Fig. 1d). From above, the mat surface appears covered by a net of honeycomb-shaped "cells" of centimeter scale in diameter. The compartments are defined by ridges and tufts of up to $3 \mathrm{~mm}$ in height. Such a pattern of compartments is a consequence of active arrangement of filaments of microorganisms (Shepard and Sumner, 2010). This arrangement possibly aids communication (signal transfer) within the microbial mat (Stoodley et al., 2002; Noffke et al., 2013). Closely comparable tufted and honeycomb patterns are observed in the Dresser Formation (Fig. 8d). They are taken to represent similar arrangement of filaments in ancient microbial mats (Fig. 16). Assuming a circular surface expression of the microbial compartments, the surface area ratio between three generations of compartments is approximately 4:1 for each of the three modal peaks across all examples studied.

\subsection{Lagoon}

4.5.1. Description. The top of the stratigraphic section recorded in the Dresser Formation is formed by a stack up to $2.80 \mathrm{~m}$ thick of black-white colored, laminated beds. This
FIG. 16. Comparison of honeycomb-like patterns of ridges and tufts on surfaces of microbial mats from the $3.48 \mathrm{Ga}$ Dresser Formation, the $2.9 \mathrm{Ga}$ Pongola Supergroup, and El Bibane, Tunisia (modern). The ratio between three generations of compartments is approximately 4:1 for each of the three modal peaks across all examples studied. Compare the structures shown in Fig. 9D. Color images available online at www .liebertonline.com/ast

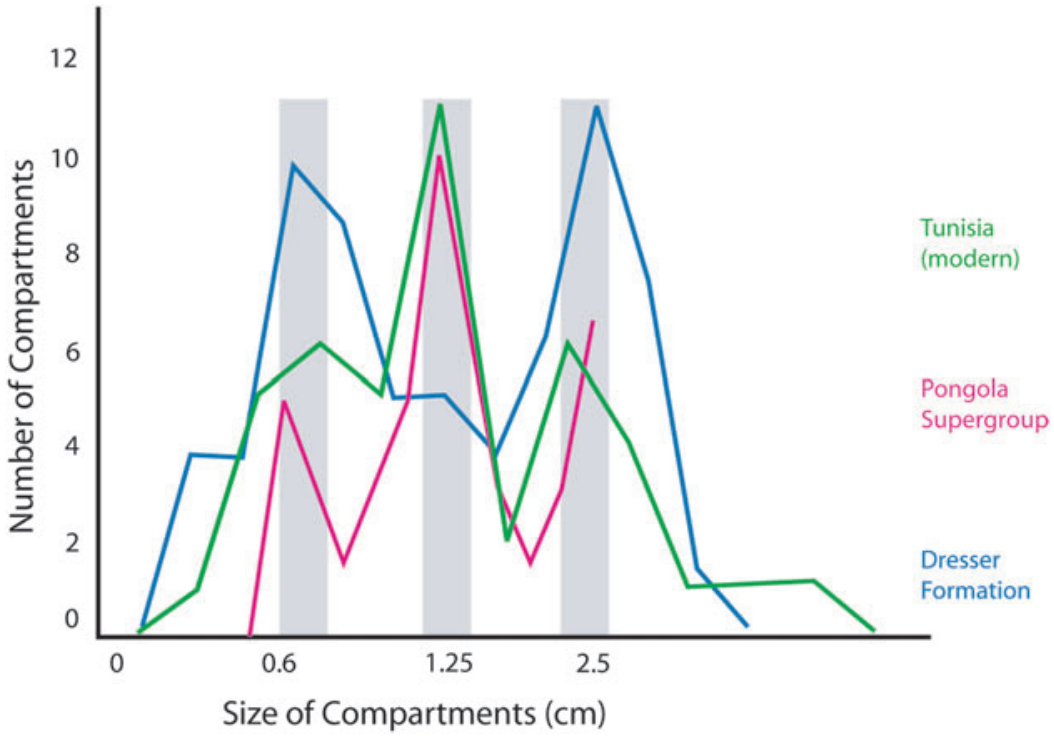




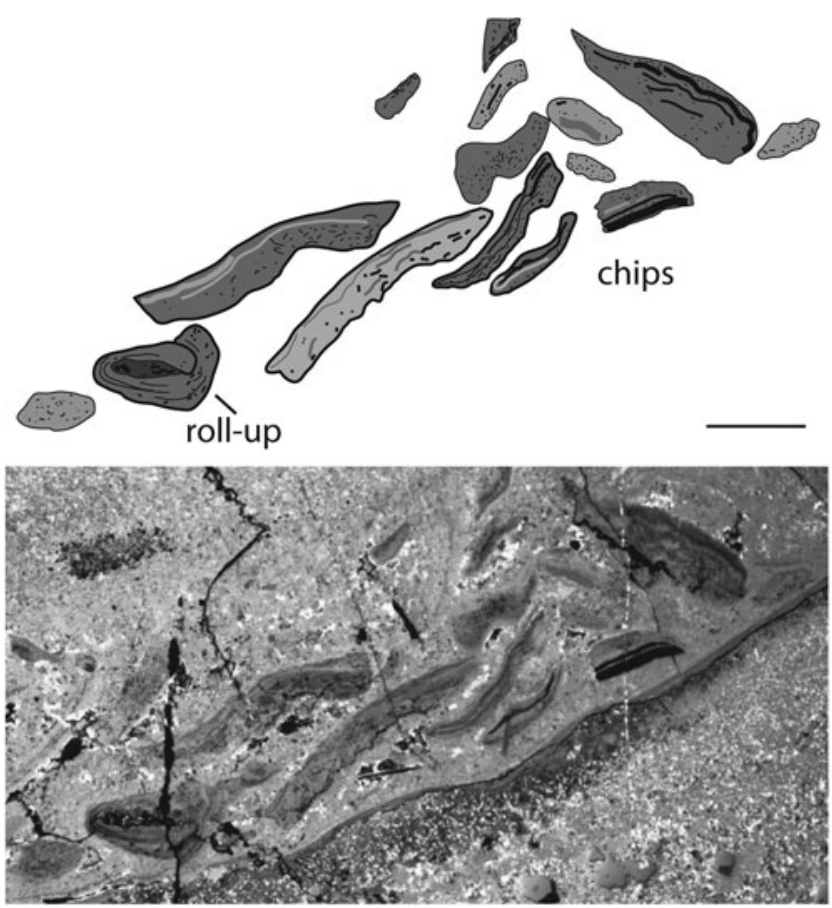

FIG. 17. Fragments in possible lagoonal deposits, microphotograph of thin section; 3.48 Ga Dresser Formation, Pilbara, Western Australia. Note the wavy appearance of the fragments. One fragment is rolled up. Geochemistry is shown in Fig. 18. Scale: $0.5 \mathrm{~cm}$.

rock unit likely records the flooding of the sabkha and the establishment of a lagoon. The planar lamination would record the gentle currents in the lagoon (Fig. 9e). Within the laminated stack, fragments of $1 \mathrm{~mm}$ to $3.5 \mathrm{~cm}$ sizes were found (Fig. 17). The fragments are flat, wavy, or even rolled up, documenting that the material of the fragments originally was soft and ductile. The fragments are of the same composition as the laminated host rock. They are composed of laminae of dark-colored goethite plus carbon alternating with laminae of translucent quartz layers. The carbon Raman signal indicates a syngenetic origin for the carbon (Fig. 18).

4.5.2. Interpretation. Modern lagoons frequently contain biolaminites (Gerdes and Krumbein, 1987). These structures are stacks of microbial mats (sometimes intercalated by sediment laminae) visible in vertical section through thick microbial mats. They can be meter-thick when developing at sites of long periods of quiet sedimentary conditions, such as in deepening lagoons or coastal sabkha lakes (Solar Lake, Red Sea, being the best example; Gerdes and Krumbein, 1987). Such biolaminites (or Stratifera when fossil) may be the origin of the thick laminated rock beds seen in the Dresser Formation (Fig. 8e comparison). The fossil fragments in these rock beds likely are microbial mat chips. The ductile nature of the organic layers is documented by their wavy appearance. One fragment is even rolled up, probably as a result of ductile response to bottom currents (Fig. 17). A laminated pattern of rock caused by hydrothermal overprint alone is unlikely, because of the preservation of chips and roll-ups of same composition in between the laminae. Also, even if hydrothermal water might have circulated through the rock, it is unlikely that the migration path of fluids would be in such a regular pattern of planes within the rock, let alone exclusively only in this certain portion of the stratigraphic profile.

\subsection{Barrier shoal}

A barrier shoal composed of oncoids (Fig. 4c) appears to have sheltered the zones described above until eventual inundation by the ocean.

\section{Ancient Microbial Mat-Forming Biota in the Dresser Formation: Thoughts and Suggestions}

A series of studies systematically comparing modern with ancient MISS showed a great consistency of MISS throughout geological time (Noffke, 2000, 2010; Noffke et al., 2001a, 2002, 2003, 2006a, 2006b, 2008). MISS assemblages record diverse microbial mat ecosystems as early as the Mesoarchean Era, as demonstrated by Noffke et al., (2001a, 2008) and Noffke (2010).

The sedimentary structures here described from the Dresser Formation are interpreted as MISS based on several lines of evidence. First, their morphologies are very similar to those of a variety of more recent fossil and modern MISS. Interpretations of these extensively studied MISS examples are based both on qualitative morphological characteristics and on numerical data that quantify the morphologies of the structures and allow quantitative comparison among MISS, as well as between MISS and nonbiological sedimentary structures. In general, transitional forms between MISS and surrounding sedimentary features are not observed, neither in modern nor fossil sequences; that is, all MISS are distinct. Variations within one morphotype of MISS occur and are considered by the quantitative data; transitional forms with intermediate morphological characteristics, however, do not exist between MISS and any abiotic type of sedimentary structure.

A second important line of evidence is provided by the close association of microbially induced sedimentary structures in the Dresser Formation. These MISS display the same associations that are known from modern as well as from fossil sabkhas.

Third, many of the sedimentary structures include microscopic biotextures resembling strongly the textures known from the younger (Archean and Proterozoic) fossil record of MISS.

Fourth, geochemical and petrological analyses are consistent with the typical mineral associations found in fossil microbial mats from other Archean sites previously described. In particular, carbon is intimately bound to the microtextures. The four complementary lines of evidence individually and collectively support the interpretation of biogenicity for MISS in the Dresser Formation.

Weathering of rock surfaces during the Eocene (Lower Tertiary) has been described in detail from other parts of Australia (van der Graff, 1983). Is there the possibility that surface weathering might mimic some of the proposed MISS features of the Dresser Formation? Tertiary weathering has produced unconsolidated soils that include irregularly shaped and steep-sloped cones, pebble-sized pisolites, and vertical karst pipes. None of these phenomena were found in the stratigraphic sections studied by us in the Pilbara. Moreover, the morphologies of the weathering 

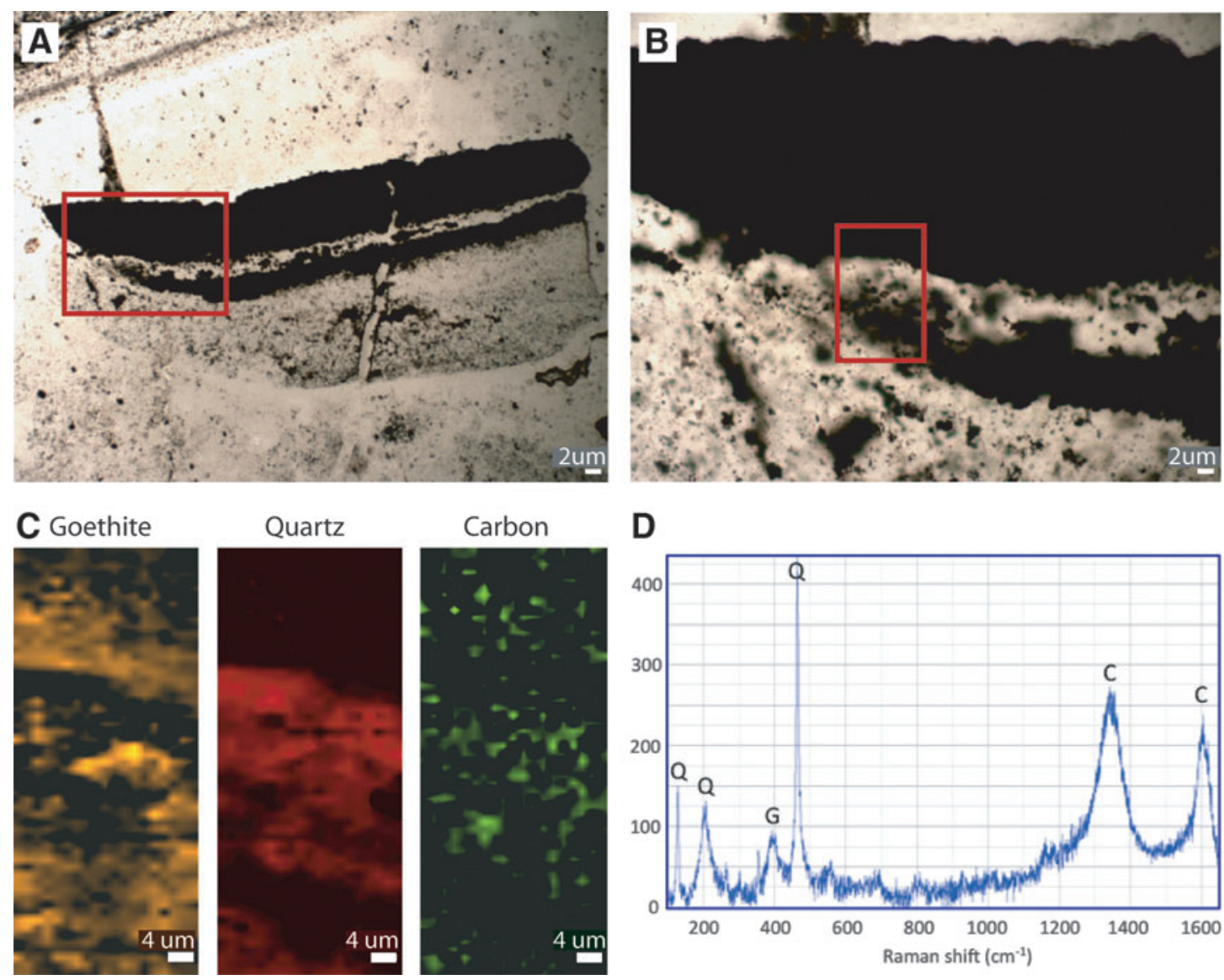

FIG. 18. Geochemistry of sedimentary fragments (see Fig. 17) in lagoonal deposits, 3.48 Ga Dresser Formation, Pilbara, Western Australia. (A) Vertical section through a typical fragment in petrographic thin section. Boxed area enlarged in (B). (B) Higher magnification view of fragment with the area analyzed using Raman indicated by the box. (C) Raman maps showing the mineralogical composition of the fragment. The goethite map was produced using the $\sim 400 \mathrm{~cm}^{-1}$ goethite Raman peak, the quartz map using the $\sim 465 \mathrm{~cm}^{-1}$ Raman quartz peak, and the carbon map using the $\sim 1600 \mathrm{~cm}^{-1}$ Raman carbon peak. (D) A typical Raman spectrum from a carbonaceous area within the fragment. This image shows background quartz $(\mathrm{Q})$ and goethite $(G)$ peaks, together with the $\sim 1350$ and $\sim 1600 \mathrm{~cm}^{-1}$ carbon peaks $(C)$ that are characteristic of thermally mature but disordered organic carbon.

structures differ significantly from those of the sedimentary structures in the Dresser Formation described as MISS. In addition, the distribution of the MISS in the Dresser Formation correlates with specific sections of the stratigraphic profiles. They are not related to the modern geomorphological topography of the study area as is the case with the weathering structures in the other parts of Australia (van der Graff, 1983). Also, the fact that the MISS form specific associations related to adjacent tidal zones differs significantly from any weathering or erosive origin, as does the identification of thermally mature carbon intimately associated with many of the Dresser structures. Finally, if the sedimentary structures we interpret as MISS were of Eocene weathering origin, then the question would be why identical MISS and MISS associations are found in modern environments of the present time that, obviously, have not experienced Eocene weathering.

We conclude that the Dresser Formation records a complex ecosystem of microbial mats. But which prokaryotes might have formed these Early Archean microbial mats? It must be underlined that modern MISS and the modern MISS-forming microbial mats may only serve as analog models for the Dresser examples. The genetic information of individual microbial groups such as modern cyanobacteria is highly variable, differing today even within meters of the same setting. Therefore, any conclusion on the existence of certain groups in the fossil record, let alone in the fossil record at $3.48 \mathrm{Ga}$, must be speculative. Also, microorganisms occur as biofilms, not as individual cells or groups. A biofilm is a microbial community attached to a solid substrate, in which all members of the community interact to foster light and nutrient harvesting, EPS production, and so on (Stoodley et al., 2002; Noffke et al., 2013). Therefore, we can with certainty state that the fossil MISS are the structural expression of biofilms formed by microbes interacting in similar fashion with the shallow, photic zone sedimentary habitat as both younger fossil and modern microbial mats do (Noffke, 2010). The main message of the Dresser Formation MISS is that microbenthos existed and was able to construct coherent, carpetlike microbial mats. The mats were able to withstand erosion, to respond to deposition, and to withstand semi-arid climate conditions. Using modern MISS and microbial mats strictly as models, we conclude that the ancient MISS-forming microbial mats in the Dresser Formation were 
dominated by microbes mimicking the behavior of modern cyanobacteria. It is important to note that cyanobacteria are one major group of microbenthos capable of producing the abundant amount of EPS necessary to allow high biostabilization effects (Linda L. Jahnke, frdl. pers. comm. 2013; Paterson et al., 1994; Noffke and Paterson, 2008; Noffke, 2010). Non-transparent wrinkle structures (Fig. 9b) record such high amounts of EPS (Noffke et al., 2002). Detailed studies on the interaction of stromatolites (Beukes and Lowe, 1989) and of MISS (Noffke et al., 2008) with their hydraulically affected sedimentary environment suggested the presence of ancient cyanobacteria already in the 2.9 Ga Pongola Supergroup, South Africa. Cyanobacteria are known to be the first oxygen-producing organisms in the fossil record. However, it is important to keep in mind that photosynthesis comes in two types, oxygenic and anoxygenic. While the abundant evidence for an anoxic atmosphere in the Early Archean (Farquhar et al., 2000; Hazen et al. 2008; Sverjensky and Lee, 2010) suggests that oxygenic photosynthesis was not established until perhaps the Neoarchean Era, it does not exclude the existence of early cyanobacteria of anoxygenic photosynthesis. However, if the stromatolite- or MISS-forming microbial mats in the Pongola Supergroup were indeed cyanobacteria with the capacity to produce oxygen, then this would be supportive to the latest findings of paleosols in the Pongola Supergroup that point toward an oxygen-rich atmosphere around that time (Crowe et al., 2013). With respect to the Dresser Formation microbiota, we note that, while a number of modern filamentous cyanobacteria are capable of anoxygenic photosynthesis, using $\mathrm{H}_{2} \mathrm{~S}$ instead of $\mathrm{H}_{2} \mathrm{O}$ as the electron donor, Chloroflexus or sulfur- or iron-oxidizing bacteria such as Beggiatoa would also be capable of this pathway (e.g., Bailey et al., 2009). Both groups also are capable of forming substantial microbial mats (e.g., Bailey et al., 2009). Pulling all these thoughts together, a conservative interpretation of the ancient Dresser microbenthos would be that the biofilms (microbial mats) of the Dresser sabkha behaved in similar fashion to modern microbenthic biofilm communities found in sabkha settings today.

In summary, the sedimentary structures preserved in the coastal sabkha paleoenvironment of the $c a$. 3.48 Ga Dresser Formation are here interpreted as MISS. The MISS form assemblages that are shown to be typical for sub-environments of sabkhas through geological time. Using modern MISS in equivalent sabkha settings as analog models, we conclude that the MISS in the Dresser Formation record a complex microbial ecosystem, hitherto unknown, and represent one of the most ancient signs of life on Earth.

\section{Acknowledgments}

We thank Kath Grey, Martin Van Kranendonk, and the Geological Survey of Western Australia for the support of our field work. Andy Knoll has provided valuable comments on an earlier version of this manuscript. Funding for this study was provided to N.N. by the National Science Foundation NSF Paleobiology and Sedimentary Geology Program, NASA's Exobiology Program, and by the NASA Astrobiology Institute. D.C. was granted student research support by the NASA Astrobiology Institute. D.W. is funded by the Bergen Research Foundation, the University of Bergen, and the Australian Research Council Centre for Core to
Crust Fluid Systems. R.M.H. received support from the NASA Astrobiology Institute, the Deep Carbon Observatory, and the Carnegie Institution of Washington.

\section{Author Disclosure Statement}

No competing financial interests exist.

\section{Abbreviations}

EPS, extracellular polymeric substances; MISS, microbially induced sedimentary structures; MOD-I, modification index.

\section{References}

Allwood, A.C., Walter, M., Kamber, B., Marshall, C., and Burch, I. (2006) Stromatolite reef from the early Archaean era of Australia. Nature 441:714-718.

Allwood, A.C., Walter, M.R., Burch, I.W., and Kamber, B.S. (2007) 3.43 billion-year-old stromatolite reef from the Pilbara Craton of Western Australia: ecosystem-scale insights to early life on Earth. Precambrian Res 158:198-227.

Allwood, A.C., Grotzinger, J.P., Knoll, A.H., Burch, I.W., Anderson, M.S., Coleman, M.L., and Kanik, I. (2009) Controls on development and diversity of Early Archean stromatolites. Proc Natl Acad Sci USA 106:9548-9555.

Allwood, A.C., Kamber, B.S., Walter, M.R., Burch, I.W., and Kanik, I. (2010) Trace elements record depositional history of an Early Archean stromatolitic carbonate platform Chem Geol 270:148-163.

Australian Stratigraphic Units Database. (2012) Dresser Formation. Geoscience Australia, Commonwealth of Australia, Canberra, Australia. Available online at http://dbforms.ga .gov.au/pls/www/geodx.strat_units.sch_full?wher= stratno $=36957$.

Awramik, S., Schopf, W., and Walter, M. (1983) Filamentous fossil bacteria from the Archean of Western Australia. Precambrian Res 20:357-374.

Bailey, J., Orphan, V., Joye, S., and Corsetti, F. (2009) Chemotrophic microbial mats and their potential for preservation in the rock record. Astrobiology 9:843-859.

Barley, M.E., Dunlop, J.S.R., Glover, J.E., and Groves, D.I. (1979) Sedimentary evidence for an Archean shallow-water volcanicsedimentary facies, eastern Pilbara block, Western Australia. Earth Planet Sci Lett 43:74-84.

Beraldi-Campesi, H., Hartnett, H.E., Anbar, A., Gordon, G.W., and Garcia-Pichel, F. (2009) Effect of biological soil crusts on soil elemental concentrations: implications for biogeochemistry and as traceable biosignatures of ancient life on land. Geobiology 7:348-359.

Beukes, N. and Lowe, D. (1989) Environmental control on diverse stromatolite morphologies in the 3000 Myr Pongola Supergroup, South Africa. Sedimentology 36:383-397.

Beveridge, T. (1989) Role of cellular design in bacterial metal accumulation and mineralization. Annu Rev Microbiol 43:147-171.

Beyssac, O., Goffe, B., Chopin, C., and Rouzaud, J.N. (2002) Raman spectra of carbonaceous material in metasediments: a new geothermometer. Journal of Metamorphic Geology 20:859-871.

Buick, R. and Dunlop, J. (1990) Evaporitic sediments of Early Archaean age from the Warrawoona Group, North Pole, Western Australia. Sedimentology 37:247-277.

Byerly, G., Lowe, D. and Walsh, M. (1986) Stromatolites from the 3,300-3,500 Myr Swaziland Supergroup, Barberton Mountain Land, South Africa. Nature 319:489-491.

Cady, S.L. and Farmer, J.D. (1996) Fossilization processes in siliceous thermal springs: trends in preservation along thermal 
gradients. In Evolution of Hydrothermal Ecosystems on Earth (and Mars?), Ciba Foundation Symposium 202, edited by G.R. Brock and J.A. Goode, John Wiley and Sons, Chichester, UK, pp 150173.

Carmona, N., Cuadrado, D., and Bournod, C. (2011) Biostabilization of sediments by microbial mats in a temperate siliciclastic tidal flat, Bahia Blanca estuary (Argentina). Sediment Geol 237:95-101.

Committee on an Astrobiology Strategy for the Exploration of Mars. (2007) An Astrobiology Strategy for the Exploration of Mars, The National Academies Press, Washington, DC.

Crowe, S.A., Dossing, L.N., Beukes, N.J., Bau, M., Kruger, S.J., Frei, R., and Canfield, D.E. (2013) Atmospheric oxygenation three billion years ago. Nature 501:535-538.

Decho, A.W., Frey, R.L., and Ferry, J.L. (2011) Chemical challenges to bacterial AHL signaling in the environment. Chem Rev 111:86-99.

Dupraz, C., Reid, P.R., Braissant, O., Decho, A.W., Norman, R.S., and Visscher P.T. (2009) Processes of carbonate precipitation in modern microbial mats. Earth-Science Reviews 96:141-162.

Eriksson, P.G., Simpson, E.L., Eriksson, K.A., Bumby, A.J., Steyn, G.L., and Sarkar, S. (2000) Muddy roll-up structures in siliciclastic interdune beds of the c. 1.8 Ga Waterberg Group, South Africa. Palaios 15:177-183.

Farquhar, J., Bao, H., and Thiemens, M. (2000) Atmospheric influence of Earth's earliest sulphur cycle. Science 289:756-758.

Fries, M. and Steele, A. (2011) Raman spectroscopy and confocal Raman imaging in mineralogy and petrography. Springer Series in Optical Sciences 158:111-135.

Gerdes, G. and Krumbein, W. (1987) Biolaminated Deposits, Springer-Verlag, Berlin.

Grotzinger, J.P., Arvidson, R.E., Bell, J.F., Calwin, W., Clark, B.C., Fike, D.A., Golombek, M., Greeley, R., Haldeman, A., Herkenhoff, K.E., Jolliff, B.L., Knoll, A.H., Malin, M., McLennan, S.M., Parker, T., Soderblom, L., Sohl-Dickstein, J.N., Squyres, S.W., Tosca, N.J., and Watters, W.A. (2005) Stratigraphy and sedimentology of a dry to wet eolian depositional system, Burns Formation, Meridiani Planum, Mars. Earth Planet Sci Lett 240:11-72.

Hagadorn, W., Pflueger, F., and Bottjer, D.J., editors. (1999) Unexplored microbial worlds. Palaios Special Issue 14.

Hazen, R.M., Papineau, D., Bleeker, W., Downs, R.T., Ferry, J.M., McCoy, T.J., Sverjensky, D.A., and Yang, H. (2008) Mineral evolution. Am Mineral 93:1693-1720.

Heubeck, C. (2009) An early ecosystem of Archean tidal microbial mats (Moodies Group, South Africa, ca. 3.2 Ga). Geology 37:931-934.

Hickman, A. (2012) Review of the Pilbara Craton and Fortescue Basin, Western Australia: crustal evolution providing environments for early life. Island Arc 21:1-31.

Hofmann, H. (2004) Archean microfossils and abiomorphs. Astrobiology 4:135-136.

Hofmann, H., Grey, K., Hickman, A., and Thorpe, R. (1999) Origin of $3.45 \mathrm{Ga}$ coniform stromatolites in the Warrawoona Group, Western Australia. Geol Soc Am Bull 111:1256-1262.

Knoll, A.H., Strother, P.K., and Rossi, S.(1988) Distribution and diagenesis of microfossils from the Lower Proterozoic Duck Creek Dolomite, Western Australia. Precambrian Res 38:257279.

Konhauser, K., Schulze-Lam, S., Ferris, F.G., Longstaffe, F.J., and Beveridge, T.J. (1994) Mineral precipitation by epilithic biofilms in the Speed River, Ontario, Canada. Appl Environ Microbiol 60:549-560.
Kremer, B., Kazmierczak, J., and Stal, L.(2008) Calcium carbonate precipitation in cyanobacterial mats from sandy tidal flats of the North Sea. Geobiology 6:46-56.

Krumbein, W.E. (1979) Photolithotrophic and chemoorganotrophic activity of bacteria and algae as related to beach rock formation and degradation (Gulf of Aquaba, Sinai). Geomicrobiol J 1:139-203.

Lambert, I.B., Donnelly, T.H., Dunlop, J.S.R., and Groves, D.I. (1978) Stable isotope compositions of early Archaean sulphate deposits of probable evaporitic and volcanogenic origins. Nature 276:808-811.

Lowe, D. (1980) Stromatolites 3,400 Myr old from the Archean of Western Australia. Nature 284:441-443.

Marshall, C.P., Emry, J.R., and Olcott Marshall, A. (2011) Haematite pseudomicrofossils present in the 3.5-billion-year old Apex Chert. Nature Geoscience 4:240-243.

Metz, J.M., Grotzinger, J.P., Rubin, D.M., Lewis, K.W., Squyres, S.W., and Bell, J.F., III. (2009) Sulfate-rich eolian and wet interdune deposits, Erebus Crater, Meridiani Planum, Mars. Journal of Sedimentary Research 79:247-264.

Noffke, N. (1999) Erosional remnants and pockets evolving from biotic-physical interactions in a Recent lower supratidal environment. Sediment Geol 123:175-181.

Noffke, N. (2000) Extensive microbial mats and their influences on the erosional and depositional dynamics of a siliciclastic cold water environment (Lower Arenigian, Montagne Noire, France). Sediment Geol 136:207-215.

Noffke, N. (2010) Microbial Mats in Sandy Deposits from the Archean Era to Today, Springer, New York.

Noffke, N. and Awramik, S. (2013) Stromatolites and MISS: differences between relatives. GSA Today 23:4-9.

Noffke, N. and Chafetz, H., editors. (2012) Microbial Mats in Siliciclastic Depositional Systems through Time, SEPM Special Publication 101, Society for Sedimentary Geology, Tulsa, OK. Noffke, N. and Krumbein, W. E. (1999) A quantitative approach to sedimentary surface structures contoured by the interplay of microbial colonization and physical dynamics. Sedimentology 46:417-426.

Noffke, N. and Paterson, D., editors. (2008) An actualistic perspective: biotic-physical interaction of benthic microorganisms and the significance for the biological evolution of Earth. Geobiology 6:1-93.

Noffke, N., Gerdes, G., Klenke, T., and Krumbein, W. (2001a) Microbially induced sedimentary structures indicating climatological, hydrological and depositional conditions within Recent and Pleistocene coastal facies zones (southern Tunisia). Facies 44:23-30.

Noffke, N., Gerdes, G., Klenke, Th., and Krumbein, W.E. (2001b) Microbially induced sedimentary structures-a new category within the classification of primary sedimentary structures. Journal of Sedimentary Research 71:649-656.

Noffke, N., Knoll, A.H., and Grotzinger, J. (2002) Sedimentary controls on the formation and preservation of microbial mats in siliciclastic deposits: a case study from the Upper Neoproterozoic Nama Group, Namibia. Palaios 17:5-33.

Noffke, N., Hazen, R., and Nhleko, N. (2003) Earth's earliest microbial mats in a siliciclastic marine environment $(2.9 \mathrm{Ga}$ Mozaan Group, South Africa). Geology 31:673-676.

Noffke, N., Beukes, N., and Hazen, R. (2006a) Microbially induced sedimentary structures in the $2.9 \mathrm{Ga}$ old Brixton Formation, Witwatersrand Supergroup, South Africa. Precambrian Res 146:35-44.

Noffke, N., Eriksson, K.A., Hazen, R.M., and Simpson, E.L. (2006b) A new window into Early Archean life: microbial mats 
in Earth's oldest siliciclastic tidal deposits (3.2 Ga Moodies Group, South Africa). Geology 34:253-256.

Noffke, N., Beukes, N., Hazen, R., Swift, D. (2008) An actualistic perspective into Archean worlds-(cyano-)bacterially induced sedimentary structures in the siliciclastic Nhlazatse Section, 2.9 Ga Pongola Supergroup, South Africa. Geobiology 6:5-20.

Noffke, N., Decho, A.W., and Stoodley, P. (2013) Slime through time- the fossil record of prokaryote evolution. Palaios 1:1-5.

Paterson, D.M., Yallop, M., and George, C. (1994) Biostabilization. In Biostabilization of Sediments, edited by W.E. Krumbein, D.M. Paterson, and L.J. Stal, BIS, Oldenburg, pp 401-432.

Prave, A.R. (2002) Life on land in the Proterozoic: evidence from the Torrodonian rocks of Northwest Scotland. Geology 30:811814.

Reid, R.P., Visscher, P.T., Decho, A.W., Stolz, J.F., Bebout, B.M., Dupraz, C., Macintyre, I.G., Paerl, H.W., Pinckney, J.L., Prufert-Bebout, L., Steppe, T.F., and des Marais, D.J (2000) The role of microbes in accretion, lamination and early lithication of modern marine stromatolites. Nature 406:989-992.

Rividi, N., van Zuilen, M., Philippot, P., Menez, B., Godard, G., and Poidatz, E. (2010) Calibration of carbonate composition using micro-Raman analysis: application to planetary surface exploration. Astrobiology 10:293-309.

Schieber, J., Bose, P.K., Eriksson, P.G., Banerjee, S., Sarkar, S., Alterman, W., and Catuneanu, O., editors. (2007) Atlas of Microbial Mat Features Preserved within the Siliciclastic Rock Record, Elsevier, Amsterdam.

Schopf, W. and Bottjer, D. (2009) World summit on ancient microscopic fossils. Precambrian Res 173:1-3.

Schopf, W., Walter, M., and Ruiji, R. (2007) Earliest evidence of life on Earth. Precambrian Res 158:139-140.

Schulze-Lam, S., Fortina, D., Davisa, B.S., and Beveridge, T.J. (1996) Mineralization of bacterial surfaces. Chem Geol 132:171-181.

Shen, Y., Buick, R., and Canfield, D.E. (2001) Isotopic evidence for microbial sulphate reduction in the early Archaean era. Nature 410:77-81.

Shen, Y., Farquhar, J., Masterson, A., Kaufman, A.J., and Buick, R. (2009) Evaluating the role of microbial sulfate reduction in the early Archean using quadruple isotope systematics. Earth Planet Sci Lett 279:383-391.

Shepard, R. and Sumner, D. (2010) Undirected motility of filamentous cyanobacteria produces reticulate mats. Geobiology 8:179-190.

Stoodley, P., Sauer, K., Davies, D.G., and Costerton, J.W. (2002) Biofilms as complex differentiated communities. Annu Rev Microbiol 56:187-209.

Sverjensky, D.A. and Lee, N. (2010) The Great Oxidation Event and mineral diversification. Elements 6:31-36.

Sugitani, K., Lepot, K., Nagaoka, T., Mimura, K., Van Kranendonk, M., Oehler, D.Z., and Walter, M.R. (2010) Biogenicity of morphologically diverse carbonaceous microstructures from the ca. 3400 Ma Strelley Pool Formation, in the Pilbara Craton, Western Australia. Astrobiology 10:899-920.

Tice, M. and Lowe, D. (2006) The origin of carbonaceous matter in pre-3.0 Ga greenstone terrains: a review and new evidence from the 3.42 Ga Buck Reef Chert. Earth-Science Reviews 76:259-300.

Ueno, Y., Yamada, K., Yoshida, N., Maruyama, S., and Isozaki, Y. (2006) Evidence from fluid inclusions for microbial methanogenesis in the early Archaean era. Nature 440:516-519.

Ueno, Y., Ono, S., Rumble, D., and Maruyama, S. (2008) Quadruple sulfur isotope analysis of $c a$. 3.5 Ga Dresser Formation: new evidence for microbial sulfate reduction in the early Archean. Geochim Cosmochim Acta 72:5675-5691.

Urrutia, M. and Beveridge, T. (1994) Formation of fine-grained metal and silicate precipitates on a bacterial surface (Bacillus subtilis). Chem Geol 116:261-280.

van der Graff, W.J.E. (1983) Silcrete in Western Australia: geomorphological settings, textures, structures, and their genetic implications. In Residual Deposits: Surface Related Weathering Processes and Minerals, Geological Society of London Special Publication 11, edited by R.C.L. Wilson, Blackwell Scientific Publications, Oxford, pp 159-166.

Van Kranendonk, M.J. (2006) Volcanic degassing, hydrothermal circulation and the flourishing of early life on Earth: a review of the evidence from c. 3490-3240 Ma rocks of the Pilbara Supergroup, Pilbara Craton, Western Australia. Earth-Science Reviews 74:197-240.

Van Kranendonk, M.J. Philippot, P., Lepot, K., Bodorkos, S., and Pirajno, F. (2008) Geological setting of Earth's oldest fossils in the ca. 3.5 Ga Dresser Formation, Pilbara Craton, Western Australia. Precambrian Res 67:93-124.

Wacey, D. (2009) Early Life on Earth: A Practical Guide, Springer, Heidelberg.

Wacey, D., McLoughlin, N., Whitehouse, M.J., and Kilburn, M.R. (2010) Two co-existing sulfur metabolisms in a ca. 3,400 Ma sandstone. Geology 38:1115-1118.

Wacey, D., Kilburn, M.R., Saunders, M., Cliff, J., and Brasier, M.D. (2011) Microfossils of sulfur metabolizing cells in $~ 3.4$ billion year old rocks of Western Australia. Nat Geosci 4:698702.

Wacey, D., Menon, S., Green, L., Gerstmann, D., Kong, C., McLoughlin, N., Saunders, M., and Brasier, M.D. (2012) Taphonomy of very ancient microfossils from the $\sim 3400 \mathrm{Ma}$ Strelley Pool Formation and 1900 Ma Gunflint Formation: new insights using focused ion beam. Precambrian Res 220221:234-250.

Walsh, M. (1992) Microfossils and possible microfossils from the Early Archean Onverwacht Group, Barberton Mountain Land, South Africa. Precambrian Res 54:271-293.

Walsh, M. and Lowe, D. (1985) Filamentous microfossils from the 3,500 Myr-old Overwacht Group, Barberton Mountain Land, South Africa. Nature 314:530-532.

Walsh, M. and Lowe, D. (1999) Modes of accumulation of organic matter in the early Archean: a petrographic and geochemical study of the carbonaceous cherts of the Swaziland Supergroup. GSA Special Paper 329:115-132.

Walter, M., Buick, R., and Dunlop, J. (1980) Stromatolites, 3,4003,500 Myr old from the North Pole area, Western Australia. Nature 284:443-445.

Address correspondence to: Nora Noffke

Department of Ocean, Earth and Atmospheric Sciences Old Dominion University Norfolk, VA 23529

E-mail: nnoffke@odu.edu

Submitted 29 April 2013 Accepted 21 October 2013 